\begin{abstract}
UNIVERSIDADE DE SÃO PAULO
FACULDADE DE FILOSOFIA, LETRAS E CIÊNCIAS HUMANAS

DEPARTAMENTO DE GEOGRAFIA

PROGRAMA DE PÓS-GRADUAÇÃO EM GEOGRAFIA HUMANA
\end{abstract}

PAUL SUTERMEISTER

A redescoberta da geografia por economistas: um comentário a partir de Geografia é destino?

(Versão corrigida)

De acordo,

Prof. Dr. José William Vesentini

São Paulo

2011 
Autorizo a reprodução e divulgação total ou parcial deste trabalho, por qualquer meio convencional ou eletrônico, para fins de estudo e pesquisa, desde que citada a fonte.

Catalogação na Publicação

Serviço de Biblioteca e Documentação

Faculdade de Filosofia, Letras e Ciências Humanas da Universidade de São Paulo

Sutermeister, Paul

A redescoberta da geografia por economistas: um comentário a partir de "Geografia é destino?": / Paul

Sutermeister ; orientador José William Vesentini. - São

Paulo, 2011.

95 f. ; il.

Dissertação (Mestrado) - Faculdade de Filosofia, Letras e Ciências Humanas da Universidade de São Paulo. Departamento de Geografia. Área de concentração: Geografia Humana.

1. Determinismo geográfico. 2. Geografia econômica. 3. Banco Interamericano de Desenvolvimento. I. Título. II. Vesentini, José William. 


\title{
A redescoberta da geografia por economistas: um comentário a partir de Geografia é destino?
}

(Versão corrigida)

\begin{abstract}
Dissertação apresentada ao
Departamento de Geografia da

Faculdade de Filosofia, Letras e Ciências Humanas da

Universidade de São Paulo para obtenção do título de Mestre em Geografia
\end{abstract}

Área de Concentração:

Geografia Humana

Orientador:

Prof. Dr. José William Vesentini

São Paulo 
Nome: SUTERMEISTER, Paul

Título: A redescoberta da geografia por economistas: um comentário a partir de Geografia é destino?

Dissertação apresentada à Faculdade de

Filosofia, Letras e Ciências Humanas da

Universidade de São Paulo para obtenção do

título de Mestre em Geografia Humana

Aprovado em:

Banca Examinadora

Prof. Dr.

Instituição:

Julgamento:

Assinatura:

Prof. Dr.

Instituição:

Julgamento:

Assinatura:

Prof. Dr.

Instituição:

Julgamento:

Assinatura: 


\section{AGRADECIMENTOS}

À minha mãe Ursula, minha avó Ingeborg e minha esposa Claudia, e nossas famílias na Suíça e na Colômbia.

Ao meu orientador Prof. Dr. José William Vesentini por ter me acolhido como orientando, contribuindo para meu crescimento enquanto pesquisador.

Aos Professores Antonio Carlos Robert Moraes e Heinz Dieter Heidemann pelas contribuições na qualificação.

Aos amigos Fabiana Cunha da Silva e Filipe Giuseppe Dal Bo Ribeiro, e a sua família, por ter me acolhido como membro de sua família.

A todos aqueles que, em momentos diversos, contribuíram para este trabalho, entre os quais: Zeno Schärer e meus amigos suíços; Alain Dick pelo estágio na Missão do Timor-Leste onde comecei a me interessar pela língua portuguesa; Ana Cristina Kerbauy; Clenes Louzeiro; os funcionários da Secretaria de Pós-Graduação do DG-FFLCH; Daniel Marcolino Claudino de Sousa; Admarcio Rodrigues; Danilo Cardoso; David Alejandro Ramírez Palacios; Diego Matos; Elidio Nhamona; Fabio Oliveira; Jailton Oliveira dos Santos; Joilson Pereira de Oliveira; Julio César Mioto; Leandro Junqueira Antoniasse; Lucia Helena Zanetti; Luciano Scarpa; Maged Talaat Mohamed Ahmed Elgebaly; Prof. Dr. Manoel Fernandes de Sousa Neto; Manuel Camilo Gil Ferreira de Medeiros; Marcos Barbosa Ferreira; Marilia Candida; Mavetse de Argos; Natalia Ordoñez; Odilon Máximo de Morais; Pablo Espíndola; Paulo Alves Silva Filho; Ramez Philippe Maalouf; Reginaldo Bittencourt; Profa. Dra. Rita de Cássia Ariza da Cruz; Robert Rodolfo da Silva; Robson Manoel N. da Silva. A Rute Frare, Cássio Augusto Santos, Nelson Pinheiro, Carlos de Carvalho Ferreira, Murilo do Val Soares e todos que estavam presentes na comemoração para Cartola. A Samarone Carvalho Marinho; Samuel Samuca Sarachini; Samuel de Souza; Sandra Regina Marcelino Pinto; Saulo Sandro Alves Dias; Talita Dias Miranda e Silva; Theo Carvalho; Thiago Araújo; Thiago A. C. Nascimento; Valdenir Máximo de Morais e muitos outros. 


\section{RESUMO}

SUTERMEISTER, P. A redescoberta da geografia por economistas: um comentário a partir de Geografia é destino?. 2011. 95 f. Dissertação (Mestrado) - Faculdade de Filosofia, Letras e Ciências Humanas; Universidade de São Paulo, São Paulo, 2011.

Apresentamos idéias geográficas contidas em Geografia é destino? (livro publicado em 2003 pelo Banco Interamericano de Desenvolvimento) e fontes afins. Focamos em David Landes, Jared Diamond e Jeffrey Sachs, considerados neste livro como "líderes da redescoberta da geografia". Eles se diferenciam da "nova geografia econômica" de Paul Krugman por terem abordagens menos matemáticas e mais focadas na história, na biologia e na política, respectivamente. Diamond nos leva a Darwin, Landes discute certa noção de influência climática sobre desenvolvimento, e Sachs sintetiza essas abordagens para compor a parte geográfica de sua nova sociologia do desenvolvimento econômico. Diamond, Landes e Sachs levam, cada um por caminhos diferentes, a uma dicotomia entre zona tropical e zonas temperadas. Concluímos com algumas observações céticas acerca destas redescobertas da "geografia".

Palavras-chave: Banco Interamericano de Desenvolvimento. Determinismo geográfico. Trópicos. 


\section{ABSTRACT}

SUTERMEISTER, P. The rediscovery of geography by economists: a commentary based on Is geography destiny?. 2011. 95 p. Thesis (MA)

- Faculty of Philosophy and Humanities, University of São Paulo, São Paulo, 2011.

We look at geographic ideas contained in Is geography destiny? (a book published in 2003 by the Inter-American Development Bank) and in related sources. We focus on David Landes, Jared Diamond and Jeffrey Sachs, who are considered as "champions of the rediscovery of geography" in this book. Their approaches differ from the "new economic geography" of Paul Krugman in being less mathematical and more focused on history, biology and policy, respectively. Diamond brings us to Darwin, Landes discusses a certain notion of climatic influence on "development", and Sachs makes a synthesis of the aforementioned approaches in order to compose the geographical part of his new sociology of economic development. Diamond, Landes and Sachs lead, each in different ways, to a dichotomy between the tropics and temperate zones. We conclude with some sceptical observations about these rediscoveries of "geography".

Keywords: Inter-American Development Bank. Geographical determinism. Tropics. 


\section{SUMÁRIO}

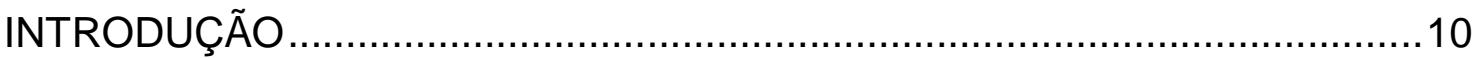

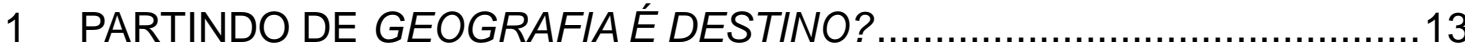

1.1 Apontamentos bibliográficos ............................................................. 13

1.2 Noções de geografia; os Trópicos ……………................................19

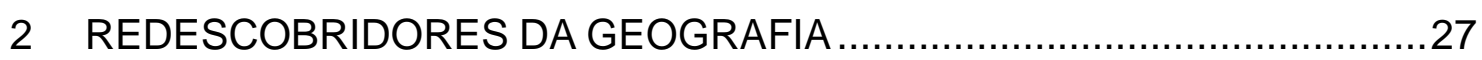

2.1 Jared Diamond; os eixos continentais ...........................................27

2.2 David Landes; desigualdades da natureza .......................................33

2.3 Jeffrey Sachs; nova sociologia do desenvolvimento econômico ..........39

2.4 Paul Krugman; geografia econômica................................................50

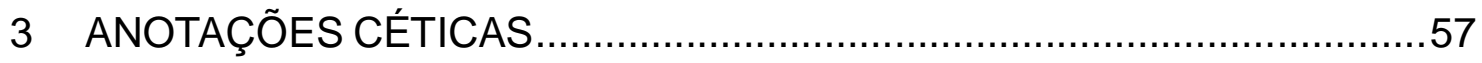

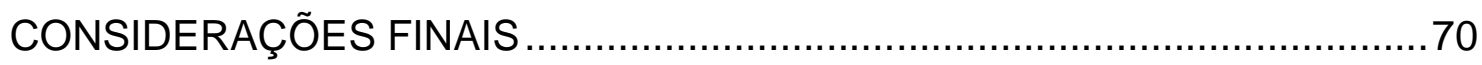

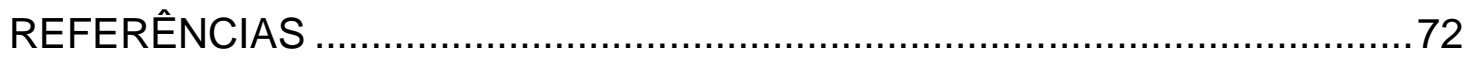

ANEXO: VESENTINI, J. W. Resenha de Geografia é destino? .......................88 
Permitam-me, agora, oferecer esboço breve, incompleto e unilateral...

(Paul Feyerabend. Contra o método: Esboço de uma teoria anárquica da teoria do conhecimento. Rio de Janeiro, F. Alves, 1977, p. 314) 


\section{INTRODUÇÃO}

Partimos de um estudo econômico intitulado Geografia é destino? (GALLUP; GAVIRIA; LORA, 2005, do Banco Interamericano de Desenvolvimento) e fontes afins que perscrutam o peso de condições geográficas $^{1}$ no atraso ou desenvolvimento da América Latina e de algumas de suas regiões, inclusive regiões dentro de países. ${ }^{2}$ Naquele livro, saltam-nos aos olhos primeiro, que o biogeógrafo Jared Diamond, o historiador David Landes e o economista Jeffrey Sachs são considerados como "líderes da redescoberta da geografia" (ibidem, p. 15), e, segundo, que para os autores do livro, "o "determinismo" é uma posição mais sensata do que o ceticismo" (ibidem, p. 16). Em que consiste essa "redescoberta da geografia"? Dedicamo-nos, no conseguinte, a esta pergunta. $^{3}$

A redescoberta da geografia que envolve Diamond, Landes e Sachs é diferente da nova geografia econômica de Paul Krugman. E as redescobertas dos três "líderes" diferem entre si em termos metodológicos. Mas todos esses autores se reúnem, de maneira variada, em Geografia é destino?, livro que visa "políticas para superar as limitações da geografia" (ibidem, capítulo 3). Para saber de qual "redescoberta da geografia" se trata, é necessário olhar de perto o "geográfico" nas idéias de cada um. Encontraremos idéias de origem matemática, relações causais de certa noção de meio (natureza não-

${ }^{1}$ Para eles, "geografia" não é discurso nem se refere a um espaço como categoria do pensamento, mas é realidade fáctico-material (termo emprestado de: MORAES, A. C. R. Território e história no Brasil. São Paulo: Annablume, 2004. p. 23).

${ }^{2}$ Agradecemos ao nosso orientador Prof. Dr. José William Vesentini pela formulação.

${ }^{3} \mathrm{O}$ presente trabalho contém trechos de nosso artigo: Jared Diamond e Paul Krugman contra David Landes e Jeffrey Sachs: genealogia contra teleologia?. Geografia, Ensino \& Pesquisa, v. 14, n. 3, 2010. Disponível em:

http://cascavel.ufsm.br/revistageografia/index.php/revistageografia/article/viewArticle/16 8. Acesso em: 29 jun. 2011. 
humana) com o ser humano, e certa regionalização do mundo (dicotomia entre zona tropical e zonas temperadas).

Nosso problema de pesquisa não é de fazermo-nos "a partilha entre o que num discurso releva da cientificidade e da verdade e o que revelaria de outra coisa; mas de ver historicamente como se produzem efeitos de verdade no interior de discursos que não são em si nem verdadeiros nem falsos" (FOUCAULT, 2009, p. 7, ver referência na página 85). Para isto, a "discussão mais pertinente aqui não é sobre o „princípio da determinação" em si [...] mas sim sobre o caráter ou a substância dessas determinações ou relações causais" (VESENTINI, 2008; ver referência na página 87). Detectamos como caráter ou como substância do "determinismo" a "influência da geografia", as "condições geográficas no maior ou menor desenvolvimento de uma região", a "geografia" como um dos "fatores que concorrem para explicar a pobreza ou riqueza das diversas regiões e países da América Latina". ${ }^{4}$

Nosso objetivo é fornecer matéria-prima para outras pesquisas, oferecer uma compilação de texto a ser analisado mais minuciosamente posteriormente. Nesta altura, ignoramos diversas críticas, por exemplo, aquelas de teorias sociais mais amplas, ou aquelas contra a dicotomia entre natureza e cultura, entre objeto e sujeito. Negligenciamos as questões quem faz tal estudo e para que; negligenciamos as condições sociais, políticas, nas quais Geografia é destino? se insere, ou seja, o contexto, que no fundo seria o que vai determinar quem tem ou não "razão", isto é, quem será mais aceito ou reproduzido academicamente. ${ }^{5}$ Limitamo-nos, na nossa dissertação, à pergunta sobre o que os autores de Geografia é destino? e as fontes afins escrevem sobre "geografia". Não nos subordinamos a um método; este vem durante a pesquisa, ou

\footnotetext{
${ }^{4}$ Agradecemos ao nosso orientador pelo comentário.

${ }^{5}$ Idem.
} 
depois; Michel Foucault é um exemplo disso: dependendo do objeto que estudou ele reformulou os seus métodos à medida que pesquisava. ${ }^{6}$

Apresentamos subsequentemente idéias "geográficas" contidas em Geografia é destino? e em textos de Jared Diamond, David Landes, Jeffrey Sachs e Paul Krugman. A redescoberta de Krugman se refere a avanços na matemática, enquanto que as redescobertas de Diamond, Landes e Sachs se referem mais ao que geógrafos costumam chamar de relação homem-meio, ou de relação sociedade-natureza. Diamond, Landes e Sachs são apresentados na sequência dos títulos principais dos autores: Diamond publicou seu livro pela primeira vez em 1997, Landes em 1998, e Sachs é o autor mais atual. Há uma continuação: Landes cita Diamond, e Sachs cita os dois. O fato de que cada um destes protagonistas "redescobre a geografia" por sua própria maneira, com bibliografia mais ou menos diferente das outras, nos permite dividir as referências de acordo com os capítulos da dissertação. Os textos citados na introdução e nos apontamentos céticos encontram-se nas referências complementares (ver p. 84). O anexo, finalmente, que está na base de nossa pesquisa, encaminha o leitor para outras possíveis abordagens de Geografia é destino?

${ }^{6}$ Idem. 


\subsection{Apontamentos bibliográficos}

Como dizem os autores de Geografia é destino? (GALLUP; GAVIRIA; LORA, 2005, p. 13), depois de pesquisar sobre economia, demografia e instituições políticas, o Departamento de Pesquisa do Banco Interamericano de Desenvolvimento (BID) (ver BANCO INTERAMERICANO DE DESENVOLVIMENTO nas referências) iniciou, por volta de 1998, uma série de pesquisas sobre a influência da "geografia" no desenvolvimento da América Latina. "Como a capacidade do Departamento de Pesquisa nessa área era limitada, os responsáveis pelo projeto (Eduardo Lora e Alejandro Gaviria) resolveram se reunir a John Luke Gallup, à época pesquisador" na Universidade Harvard (GALLUP; GAVIRIA; LORA, 2005, p. 13). Gallup "já estava trabalhando com a questão da geografia com Jeffrey Sachs" (ibidem). Os três autores, John Luke Gallup (PORTLAND STATE UNIVERSITY), Alejandro Gaviria (UNIVERSIDAD DE LOS ANDES) e Eduardo Lora (BANCO INTERAMERICANO DE DESENVOLVIMENTO), são formados em economia.

Esses autores decidiram "contratar algumas pesquisas exploratórias em diversos países, sob os auspícios da Rede de Centros de Pesquisa da América Latina do BID" (rede que foi criada pelo BID "em 1991 a fim de fortalecer a formulação de políticas e contribuir para o programa de políticas de desenvolvimento na América Latina") (GALLUP; GAVIRIA; LORA, p. 13). "Por intermediário de um processo de licitação competitivo, a rede forneceu recursos para nove estudos de caso" (BANCO INTERAMERICANO DE DESENVOLVIMENTO), entre os quais dois estudos brasileiros (ibidem, p. 13-14): ALVES et al., 2000; e AZZONI et al., 2000. 
O livro que resultou dessa colaboração, Geografia é destino?, faz parte da Série Fórum Latino-americano de Desenvolvimento, editada em idioma inglês pela Stanford University Press (BANCO INTERAMERICANO DE DESENVOLVIMENTO). A série é patrocinada pelo BID, pela Comissão Econômica para a América Latina e o Caribe (CEPAL) e pelo Banco Mundial. O "conselho consultivo" para essa série é constituído majoritariamente por economistas da CEPAL, do BID e do Banco Mundial (GALLUP; GAVIRIA; LORA, 2005, p. 5).

Além dos nove estudos de caso da Rede de Centros de Pesquisa da América Latina do BID, acima mencionados, o livro Geografia é destino? contém uma bibliografia (ibidem, p. 157-164) relativamente diversificada; constam: textos elaborados no seio de organizações governamentais (internacionais) (entre quais os nove estudos de caso, acima mencionados); artigos publicados em revistas (econômicas), abordando temas especificamente econômicos, escritos majoritariamente por economistas; livros sobre temas mais vastos de autores contemporâneos que, na maioria, não são formados em economia, e que compartem certo interesse em explicar as diferenças sócio-econômicas no mundo através de processos que poderíamos chamar de transhistóricos: Alfred Crosby (1972 e 1986), Jared Diamond (1997), Brian Fagan (1999), James Gleick (1999), Marvin Harris (1987), David Landes (1998), David McCullough (1977), William McNeill (1976), Matt Ridley (1999), Jeffrey Sachs (1999 e 2002), Jonathan Weiner (1999), Eric Williams (1964) e Karl Wittfogel (1981; conhecido pela teoria do despotismo oriental). A bibliografia ainda contém obras de autores nãocontemporâneos ou não-classificáveis nas categorias acima enunciadas: Francis Galton (primo de Charles Darwin), Ellsworth Huntington e Arthur e Alan Strahler (1992; os geocientistas de cuja obra Gallup, Gaviria e Lora (2005, p. 22, 23 e 33) extraem o sistema de classificação climática Köppen-Geiger), e Edgar Thompson (sociólogo e autor de uma "teoria climática de plantação"). Em outras palavras, o livro está caracterizado "pela quase total ausência de uma bibliografia geográfica, de pesquisas 
de fato geográficas e atuais"; os autores "utilizaram um material em geral ultrapassado, salvo raras exceções" (VESENTINI, 2006; ver anexo p. 88 de nossa dissertação).

Entre aquelas exceções encontramos, provavelmente, as seguintes. Na primeira frase da introdução de Geografia é destino?, os autores enfatizam três autores, considerados como "líderes da redescoberta da geografia":

Após várias décadas de indiferença e desconfiança, economistas e outros cientistas sociais redescobriram a geografia. Os líderes dessa redescoberta foram intelectuais do porte de David Landes, Jared Diamond e Jeffrey Sachs, para citar alguns. (GALLUP; GAVIRIA; LORA, 2005, p. 15)

Inspirados por estes "célebres autores" (ibidem, p. 13), Gallup, Gaviria e Lora iniciaram a "série de pesquisas sobre a influência da geografia no desenvolvimento da América Latina" (idem) que resultou em Geografia é destino?. Dedicaremos a cada um dos três um capítulo que resume idéias geográficas centrais do respectivo autor (Diamond: capítulo 2.1; Landes: capítulo 2.2; Sachs: capítulo 2.3).

Além destes três "líderes da redescoberta da geografia", destacamse, certamente, os outros autores dos livros sobre temas mais vastos acima enunciados, entre quais os seguintes. O historiador Alfred W. Crosby com seu Imperialismo ecológico: a expansão biológica da Europa, 900-1900 (1986), obra biogeográfica e sobre ecologia humana (cf. GALLUP; GAVIRIA; LORA, 2005, p. 28-29), que é a continuação de um estudo do mesmo autor intitulado $O$ intercâmbio colombiano: conseqüências biológicas e culturais de 1492, publicado uma década antes; Imperialismo ecológico serviu também como fonte para Armas germes e aço de Jared Diamond (1997; o autor que abordamos no capítulo 2). De David McCullough (1977), quem conta uma história do Canal de Panamá, os autores de Geografia é destino? tiram as 
impressões sobre o efeito do calor sobre a saúde humana que compõem uma parte intitulada Trópicos inóspitos, porém não indomáveis (GALLUP; GAVIRIA; LORA, 2005, p. 33 e 41); as idéias dele são parecidas aos "efeitos diretos" evocados por Landes (ver página 35 de nossa dissertação).

\section{Os clássicos ${ }^{7}$}

Num artigo intitulado Prisioneiros da geografia (prisoners of geography), o anterior economista-chefe do BID Ricardo Hausmann (2001), mencionado nos agradecimentos de Geografia é destino? (GALLUP; GAVIRIA; LORA, 2005, p. 14), diz que a geografia influencia a riqueza e a pobreza das populações através do "acesso aos mercados" de Adam Smith e da "destruição criadora" de Joseph Schumpeter (ibidem, p. 46-47); Smith e Schumpeter (junto com David Ricardo) estão certamente no centro das redescobertas da "geografia" que abordamos no nosso trabalho.

Adam Smith (2003) aborda o "acesso a mercados" e a "divisão de trabalho" no terceiro capítulo da obra $A$ riqueza das nações. Características da superfície terrestre influenciariam os padrões de assentamento e circulação humanos. Essas características facilitariam ou freiariam, através dos custos de transporte e comunicação, o contato entre as pessoas, e assim causariam maior ou menor troca de bens e idéias. A extensão de um mercado influenciaria, assim, a quantidade de trocas possíveis que, por sua vez, determinaria o grau de divisão de trabalho (ibidem, p. 23):

Quando o mercado é muito reduzido, ninguém encontra estímulo para dedicar-se exclusivamente a uma atividade, uma vez que não haverá a possibilidade de trocar todo o

\footnotetext{
${ }^{7}$ Para os trechos expostos a seguir repetimos que estamos fazendo um esboço breve, incompleto e unilateral / acrítico (ver epígrafe p. 9).
} 
excedente de produção do trabalho que supera o próprio consumo pelo excedente de produção do trabalho de outros homens de que tenha necessidade.

Para certos economistas, a divisão do trabalho é fonte de bem-estar para os seres humanos: dizem que, na medida em que se facilitaria o contato entre pessoas, aumentaria seu bem-estar. Ou, como diz David Ricardo (1996, p. 97):

Num sistema comercial perfeitamente livre, cada país naturalmente dedica seu capital e seu trabalho à atividade que the seja mais benéfica. Essa busca de vantagem individual está admiravelmente associada ao bem universal do conjunto dos países. Estimulando a dedicação ao trabalho, recompensando a engenhosidade e propiciando o uso mais eficaz das potencialidades proporcionadas pela natureza, distribui-se o trabalho de modo mais eficiente e mais econômico, enquanto, pelo aumento geral do volume de produtos, difunde-se 0 benefício de modo geral e une-se a sociedade universal de todas as nações do mundo civilizado por laços comuns de interesse e de intercâmbio. ${ }^{8}$

A "destruição criadora", por sua vez, é explicada no capítulo 7 da obra Capitalismo, Socialismo e Democracia de Joseph Schumpeter (1961). Para este economista, o conceito significa "processo de mutação industrial - se é que podemos usar esse termo biológico - que revoluciona incessantemente a estrutura econômica a partir de dentro, destruindo incessantemente o antigo e criando elementos novos" (ibidem, p. 106). O ritmo dessa mutação dependeria da quantidade de trocas possíveis de bens e idéias que, por sua vez, seria influenciada pela extensão do mercado: quanto maior a densidade populacional e a circulação (ou o

\footnotetext{
${ }^{8}$ No seu artigo Ricardo's difficult idea, Krugman (1996) aproxima a teoria da "vantagem comparativa" àquela de Darwin sobre a seleção natural, dizendo que ambas operam com coisas complexas, mas inteligíveis de maneira similar.
} 
comércio), tanto maior a destruição criadora, tanto mais inovação tecnológica - o que equivaleria a progresso/aumento do bem-estar.

O papel de Smith, Ricardo e Schumpeter para as redescobertas da geografia que abordamos estão à espera de análises mais minuciosas.

No mesmo artigo ("Prisioneiros da geografia"), Hausmann (2001) diz que existe uma dicotomia entre baixas (menos desenvolvidas) e altas (mais desenvolvidas) latitudes. Hausmann (2001, p. 53) nos oferece também a seguinte bibliografia para explicar a relação entre "geografia" e pobreza: autores

que enfatizam "o papel crucial da geografia na história da humanidade": Jared Diamond, Lawrence E. Harrison (cientista político), Samuel Huntington (cientista político), David Landes, William H. McNeill, e Jeffrey Sachs;

- que estudam a "relação entre fatores geográficos e o progresso socioeconômico": Raymond Arsenault (historiador), John Luke Gallup e Andrew D. Mellinger; e

- que estabelecem uma relação entre geografia e distribuição de ingresso (Michael Gavin, ecólogo), entre recursos naturais e desenvolvimento institucional (Stanley Engerman, economista, e Kenneth Sokoloff, economista e historiador), e entre "geografia e pensamento econômico contemporâneo" (Paul Krugman, economista). 


\subsection{Noções de geografia; os Trópicos}

O objetivo dos autores de Geografia é destino? (GALLUP, GAVIRIA, LORA; 2005, p. 13) é, de maneira geral, "provar que a geografia influencia o desenvolvimento" (ibidem, p. 16). Os objetivos específicos são explicar 1) por que "alguns países da América Latina não conseguem crescer a um ritmo satisfatório mesmo tendo seguido todas as recomendações prescritas pelos economistas", e 2) por que "as desigualdades são maiores nas sociedades latino-americanas do que em outras regiões" (ibidem, p. 13).

Por "pobreza", eles entendem uma baixa renda per capita. A "geografia", por sua vez, seria "um conceito que abarca várias dimensões" (ibidem, p. 16); trata-se do "estudo da Terra, de suas características e da vida que ela sustenta" (ibidem, p. 18). O desenvolvimento econômico e social seria "influenciado tanto pela geografia física (clima e características do solo e da topografia) quanto pela geografia humana (padrões de assentamento da população)" (ibidem, p. 18). Em outras palavras, a "geografia afeta o desenvolvimento pela interação entre as características físicas da paisagem - como clima, topografia e qualidade do solo - e os padrões de assentamento das populações" (ibidem, p. 21).

Mais concretamente, como os economistas nos dizem, a "geografia influencia o desenvolvimento econômico e social por meio de quatro canais básicos: produtividade da terra, condições de saúde [presença de doenças endêmicas], freqüência e intensidade dos desastres naturais e acesso aos mercados [localização dos países e de suas populações com relação ao litoral, concentração da população nas áreas urbanas]" (ibidem, p. 18 e 22). Esses "canais interagem com a distribuição espacial da população e da produção que, por sua vez, é amplamente endógena aos fatores geográficos" (ibidem, p. 22).

Os autores admitem que possa haver outras "influências que atuam no sentido contrário - isto é, do desenvolvimento (ou a falta dele) para a 
geografia": efeitos da erosão, poluição, super-exploração dos recursos naturais sobre a sustentabilidade ambiental (ibidem, p. 22). Mas "esses canais de influência foram objeto de mais análises do que os efeitos imediatos da geografia sobre o desenvolvimento" (ibidem, p. 22).

A fim de identificar os "fatores geográficos" que teriam "impacto sobre a atividade econômica e a distribuição da população" de uma região (ibidem, p. 23), ${ }^{9}$ Gallup, Gaviria e Lora (ibidem, p. 22) começam com o clima, com o sistema de classificação climática de Wladimir Köppen, modificado por Rudolf Geiger, do qual apresentam ecozonas baseadas "em dados de temperatura e de precipitação, bem como na altitude" (ibidem, p. 22; cf. STRAHLER; STRAHLER, 1992, p. 155-160). "A sobreposição das ecozonas de Köppen com [...] modelos simples de localização [relacionadas com acesso a mercado] configura a base" de um zoneamento que os autores usam nas páginas posteriores (GALLUP; GAVIRIA; LORA, 2005, p. 23). E como diz o título da parte que começa na página 23 (ibidem), "zonas geográficas diferentes" levam a "resultados econômicos diferentes". No conseguinte, Gallup, Gaviria e Lora (ibidem, p. 24-25) destacam a densidade populacional: "A cosequência da densidade do PIB per capita e da população é a densidade da produção econômica por área de terra" (ibidem, p. 25). Quanto maior a densidade populacional, e quanto mais longe da linha do equador, tanto maior a produção econômica (ibidem).

Outro aspecto seria a "fragmentação geográfica da população" (ibidem, p. 25-27) pela qual os autores desenvolveram um índice que eles apresentam num diagrama na página 26. Entende-se por "fragmentação geográfica" a "probabilidade de que dois indivíduos escolhidos ao acaso não vivam em ecozonas semelhantes" (ibidem, p. 25). "Em geral, a fragmentação aumenta à medida que cresce o número de ecozonas e o peso de cada grupo se equipara" (ibidem).

\footnotetext{
${ }^{9}$ Neste caso, da América Latina.
} 
Normalmente, há uma diferença cultural muito grande entre os habitantes das diferentes ecozonas - por exemplo, o contraste entre os expansivos e falantes moradores da planície e os tímidos e calados habitantes das regiões montanhosas tornou-se um dos nossos clichês mais verdadeiros. Igualmente, a composição da economia difere bastante entre as ecozonas [...]. Assim, a fragmentação geográfica é uma dimensão do conflito social [...]. Como consequência da divisão geográfica, os diferentes grupos sociais podem enfrentar diferentes situações que afetam suas possibilidades econômicas, e podem ter interesses econômicos e problemas sociais distintos, os quais podem influenciar o jogo político e, em última análise, todos os aspectos do desenvolvimento. (ibidem, p. 25-27)

Na parte seguinte, sobre história (ibidem, p. 28-41), Gallup, Gaviria e Lora abordam certa macroecologia humana baseada em William McNeill (1976), Alfred Crosby (1972 e 1986) e Jared Diamond (1997) segundo qual a América foi necessariamente colonizada por europeus, e não o inverso; no capítulo 2.1 de nossa dissertação entraremos mais no assunto.

Vimos mais acima que haveria quatro campos de problemas agricultura, saúde, gestão de desastres naturais e acesso a mercados próprios à maioria dos países pobres do mundo que "está localizada nos trópicos, enquanto os níveis mais elevados de desenvolvimento encontram-se nas áreas não-tropicais" (ibidem, p. 42). Uma pressuposição básica é que o conhecimento e a tecnologia nos campos da agricultura, da saúde e da gestão de desastres naturais são diferentes na zona tropical (ou seja, mais ou menos entre as linhas geográficas imaginárias dos trópicos de Capricórnio e Câncer), que nas zonas temperadas (possa ser mais apropriado falar de baixas ou altas 
latitudes ${ }^{10}$ mas continuamos com zona(s) tropical(is) e temperada, respectivamente, porque são os termos usados pelos autores de Geografia é destino?).

Os indicadores que sintetizam "os principais canais de influência da geografia" são, segundo Gallup, Gaviria e Lora (2005, p. 72): a porcentagem da terra nos trópicos (de um país), a distância (absoluta) do principal mercado em quilômetros (de um país), a porcentagem da população urbana (de um país), a porcentagem da população distante até 100 km do litoral ou de um rio (de um país), e o índice de malária (ibidem; ver figura 1).

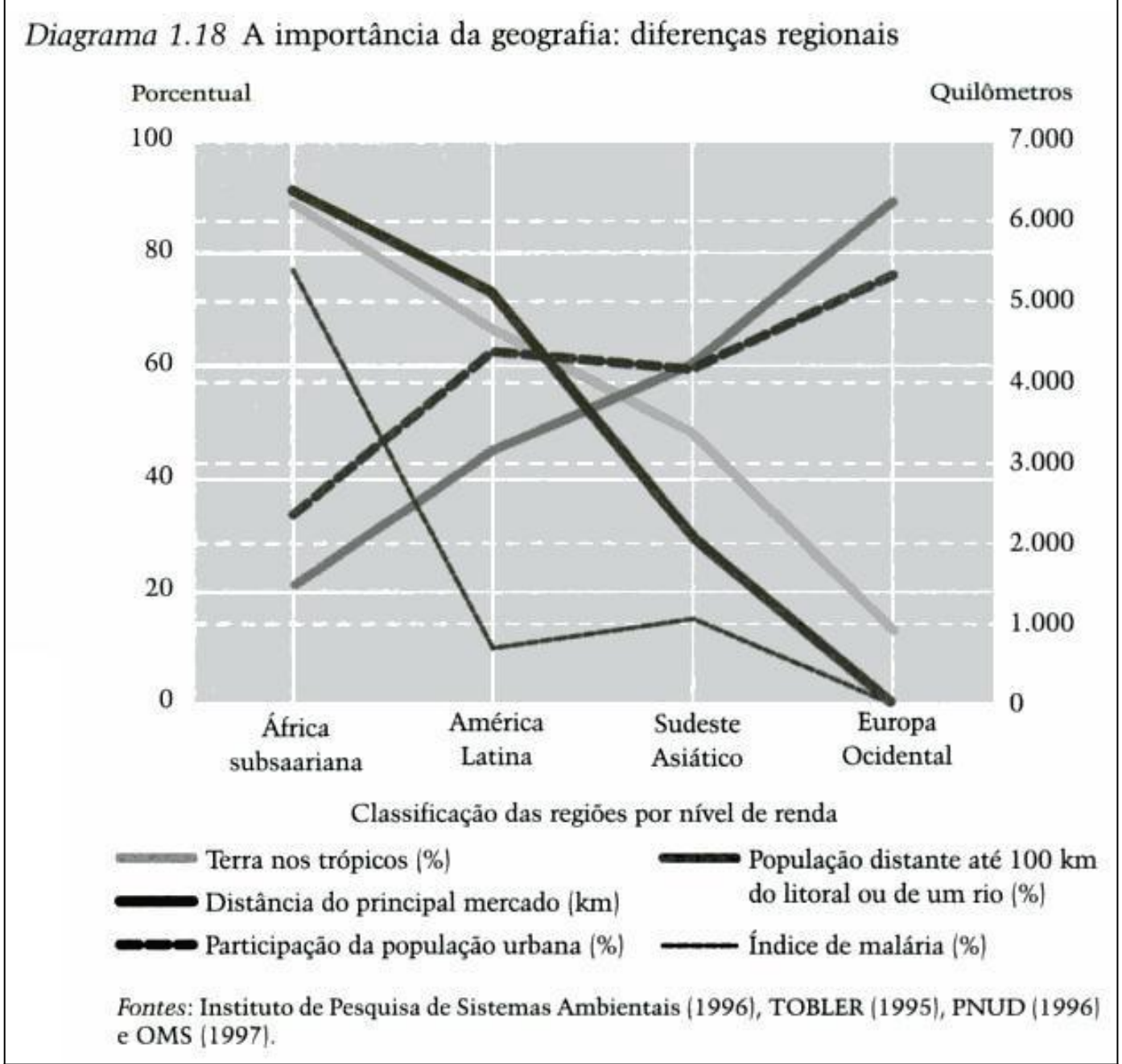

Figura 1 - "Principais canais de influência da geografia" (GALLUP; GAVIRIA; LORA, 2005, p. 72).

\footnotetext{
${ }^{10}$ Anotações da Disciplina Geografia e Tropicalidade de José Bueno Conti, FFLCH-USP, abril de 2010.
} 
O primeiro indicador é a localização tropical, um substituto para as desvantagens tecnológicas da produtividade da terra e da agricultura, que é medido pelo porcentual da área do país dentro dos trópicos geográficos. O segundo indicador, a preponderância da malária, é a principal medida do ônus da doença provocado por fatores puramente geográficos. Ele é um índice que considera tanto o porcentual da população com risco de contrair malária quanto o porcentual da população infectada que sofre dos tipos mais graves de malária. (Descrições mais detalhadas dessas variáveis podem ser encontradas em GALLUP; SACHS; MELLINGER 1999 [Nota de rodapé; N. A.]) O terceiro indicador reflete a proximidade dos países de cada região dos principais mercados mundiais, medindo a distância em quilômetros da capital do país de Tóquio, Nova York e Roterdã. Quarto, o acesso interno do país ao mar é medido pelo porcentual da população que mora dentro de uma faixa de $100 \mathrm{~km}$ da costa ou de um rio navegável que deságüe no oceano. Para países que não têm saída para o mar, o porcentual será zero. Finalmente, a urbanização é medida como o porcentual da população que mora em áreas urbanas (de acordo com a definição para cada país; ver PNUD, 1996). (GALLUP; GAVIRIA; LORA 2005, p. 73)

Para os autores de Geografia é destino?, "esses cinco indicadores simples fornecem uma boa síntese das vantagens ou desvantagens geográficas de cada uma das principais regiões do mundo" (GALLUP; GAVIRIA; LORA 2005, p. 73). Eles observam ainda "que falta um indicador sintético para um de nossos canais de influência da geografia, a saber, a propensão de que ocorram desastres naturais"; numa tabela em Geografia é destino?, os autores utilizam "como indicador aproximado os índices de comunicação de mortes provocadas por terremotos e erupções vulcânicas [...]" (GALLUP; GAVIRIA; LORA, 2005, p. 73). 
Veremos mais na frente que Jeffrey Sachs fornece aos autores de Geografia é destino? argumentos para considerar, no que se refere a "desenvolvimento", uma dicotomia entre zona tropical e zonas temperadas. Os autores de Geografia é destino? tentam provar tal dicotomia através de estatísticas do Banco Mundial, do Environmental Systems Research Institute (ESRI) e da Organização das Nações Unidas (ONU), como veremos nas seguintes gráficas. Eles estabelecem uma relação direta entre latitude e Produto Interno Bruto (PIB) médio per capita (figura 2), entre latitude e taxa de mortalidade infantil (figura 3) assim como entre latitude e expectativa de vida (figura 4), respectivamente sendo, nos três casos, os valores para baixas latitudes (zona tropical) piores que para altas latitudes (zonas temperadas).

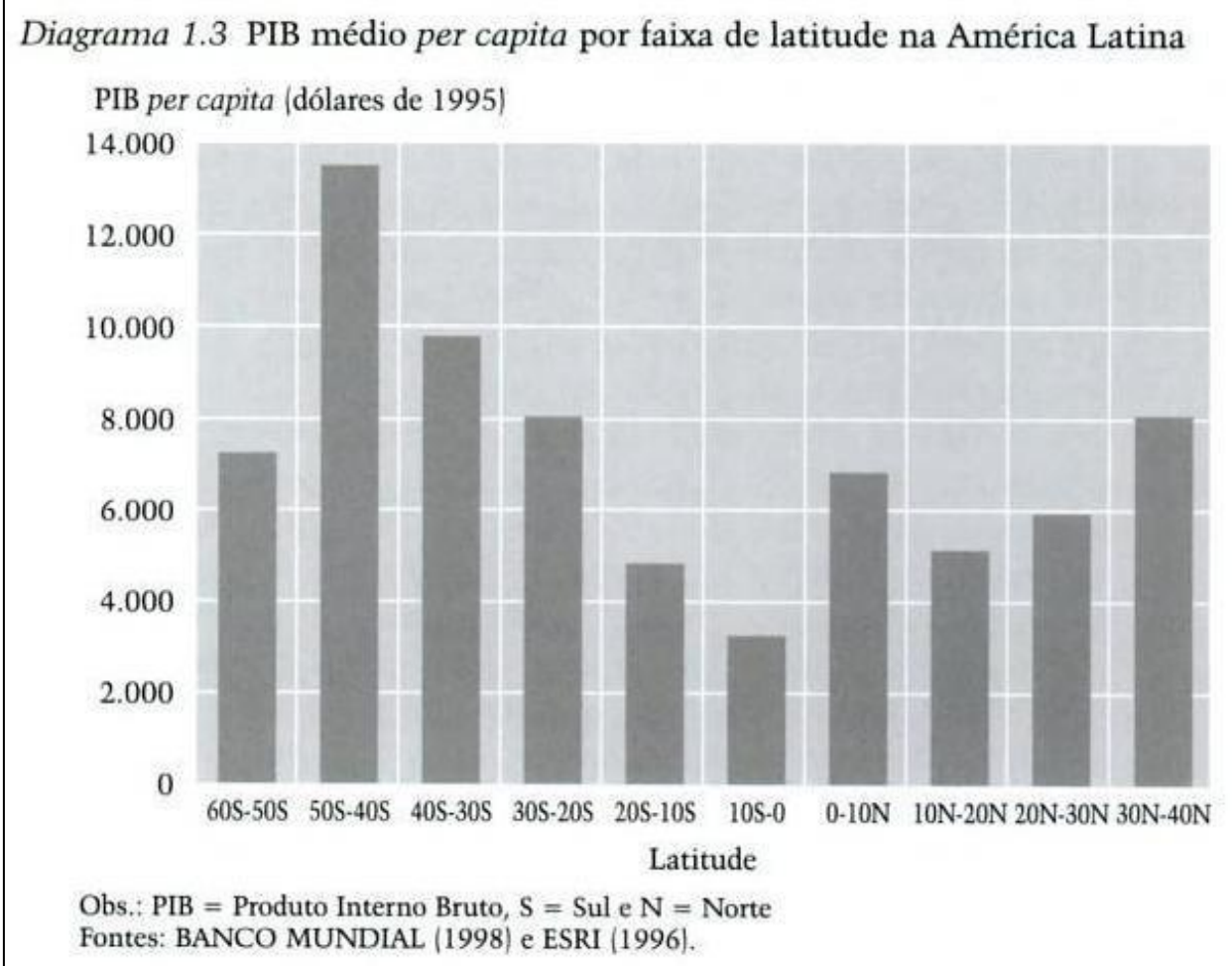

Figura 2 - Relação entre latitude e PIB médio per capita (GALLUP; GAVIRIA; LORA, 2005, p. 42). 
Diagrama 1.8 Mortalidade infantil por faixa de latitude

Mortalidade infantil/1.000 nascidos vivos

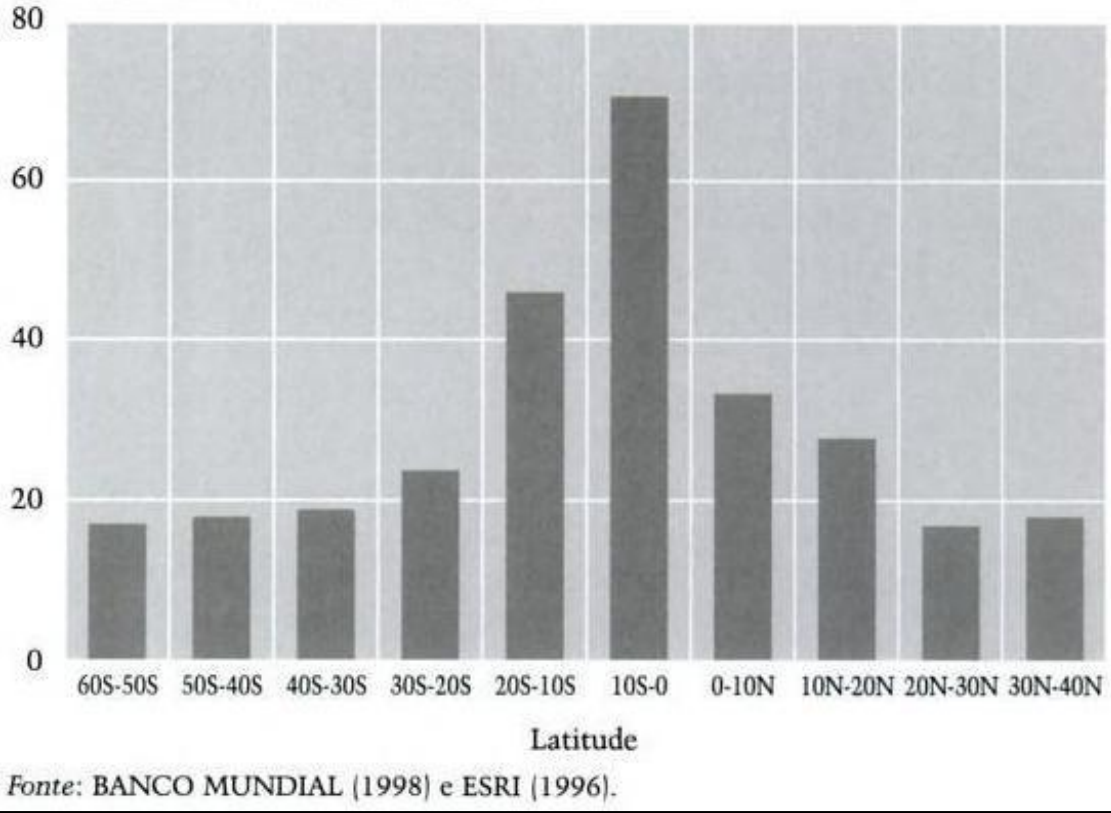

Figura 3 - Relação entre latitude e mortalidade infantil (GALLUP; GAVIRIA; LORA, 2005, p. 52).

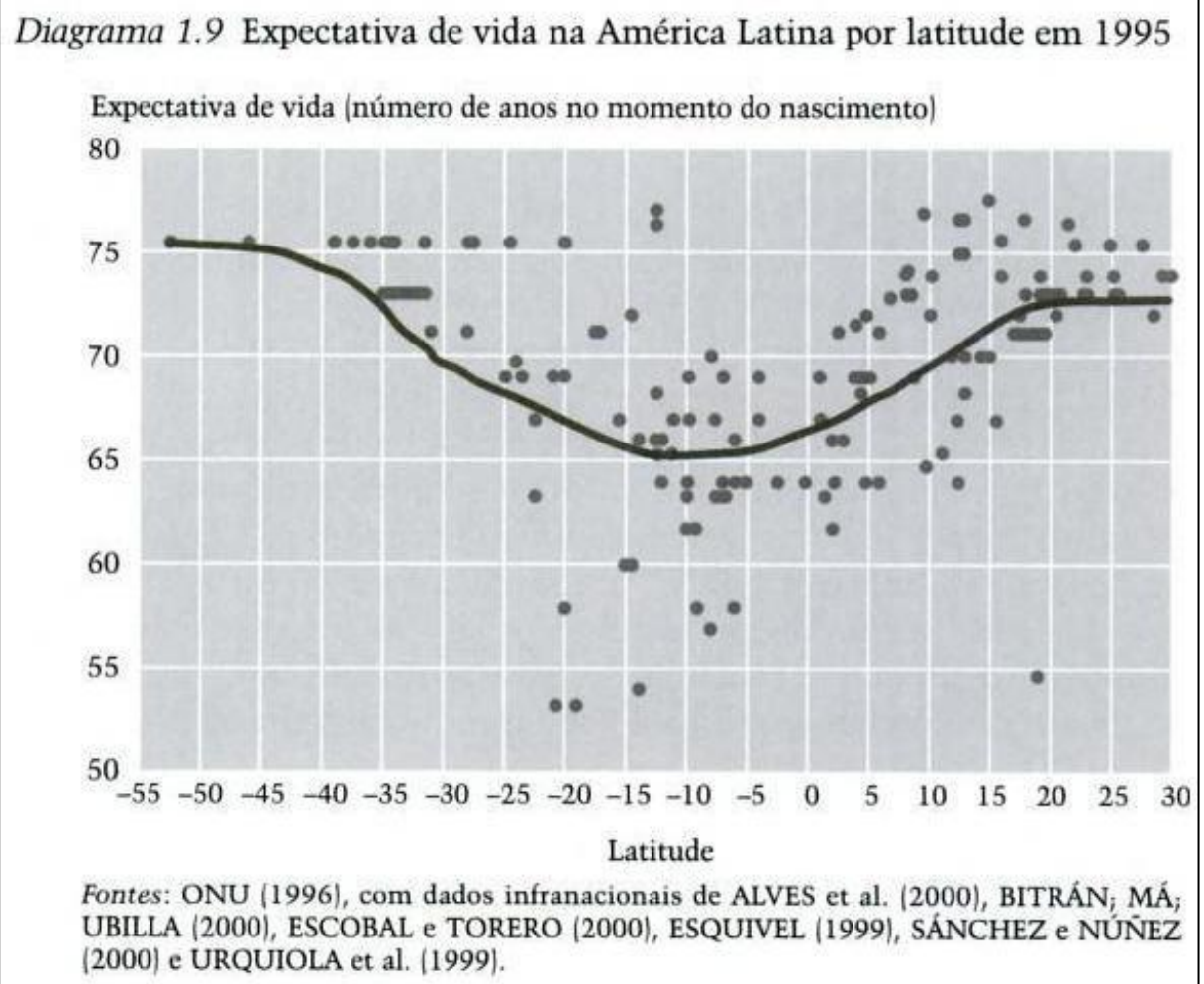

Figura 4 - Relação entre latitude e expectativa de vida (GALLUP; GAVIRIA; LORA, 2005, p. 52). 
Gallup, Gaviria e Lora (2005, p. 42) escrevem: "Se a geografia não fosse importante, a expectativa seria encontrar condições econômicas similares por todo o mundo, sujeitas a alguma variação aleatória". Eles admitem que na "América Latina há mais países de renda média nos trópicos do que em outras regiões com áreas tropicais, indicando estar menos sujeita à regra geral de que os trópicos são mais pobres" (ibidem). Mas "a maioria dos países pobres do mundo está localizada nos trópicos, enquanto os níveis mais elevados de desenvolvimento encontram-se nas áreas não-tropicais" (ibidem). 


\section{REDESCOBRIDORES DA GEOGRAFIA}

\subsection{Jared Diamond; os eixos continentais}

O biólogo e geógrafo Jared Diamond formou-se na Universidade de Harvard. Viveu durante muitos anos na Papua - Nova Guiné. O único livro de Diamond que consta na bibliografia de Geografia é destino? é Armas, germes e aço (DIAMOND, 1997); foi vencedor do Prêmio Pulitzer. É difícil resumir a vida ou a obra de uma pessoa viva; sobre este autor muito citado e comentado, qualquer consulta em Google oferece informações melhores, mais atuais, do que aquelas que poderíamos colocar aqui. ${ }^{11}$

Segundo Diamond (1997, contracapa), "a dominação de uma população sobre outra tem fundamentos militares (armas), tecnológicos (aço) ou nas doenças epidêmicas (germes), que dizimaram sociedades de caçadores e coletores, assegurando conquistas." Esses seriam fatores imediatos, ou próximos "que marcaram um padrão mais amplo da história" (ibidem, p. 85).

Os fatores próximos baseiam-se em fatores fundamentais, ou fatores últimos: 1) as formas dos continentes, entre quais os "eixos" dos continentes e a fragmentação da Europa; 2) a distribuição geográfica de plantas (e animais) selvagens domesticáveis; e 3 ) as barreiras geográficas que impedem a difusão de "domesticáveis".

11 Baseamo-nos nas incertezas de: FOUCAULT, Michel. O que é um autor? In: Estética: literatura e pintura, música e cinema. Ditos \& Escritos III. Rio de Janeiro: Forense Universitária, 2006. p. 264-298. 
Fatores que marcaram um padrão mais amplo da história

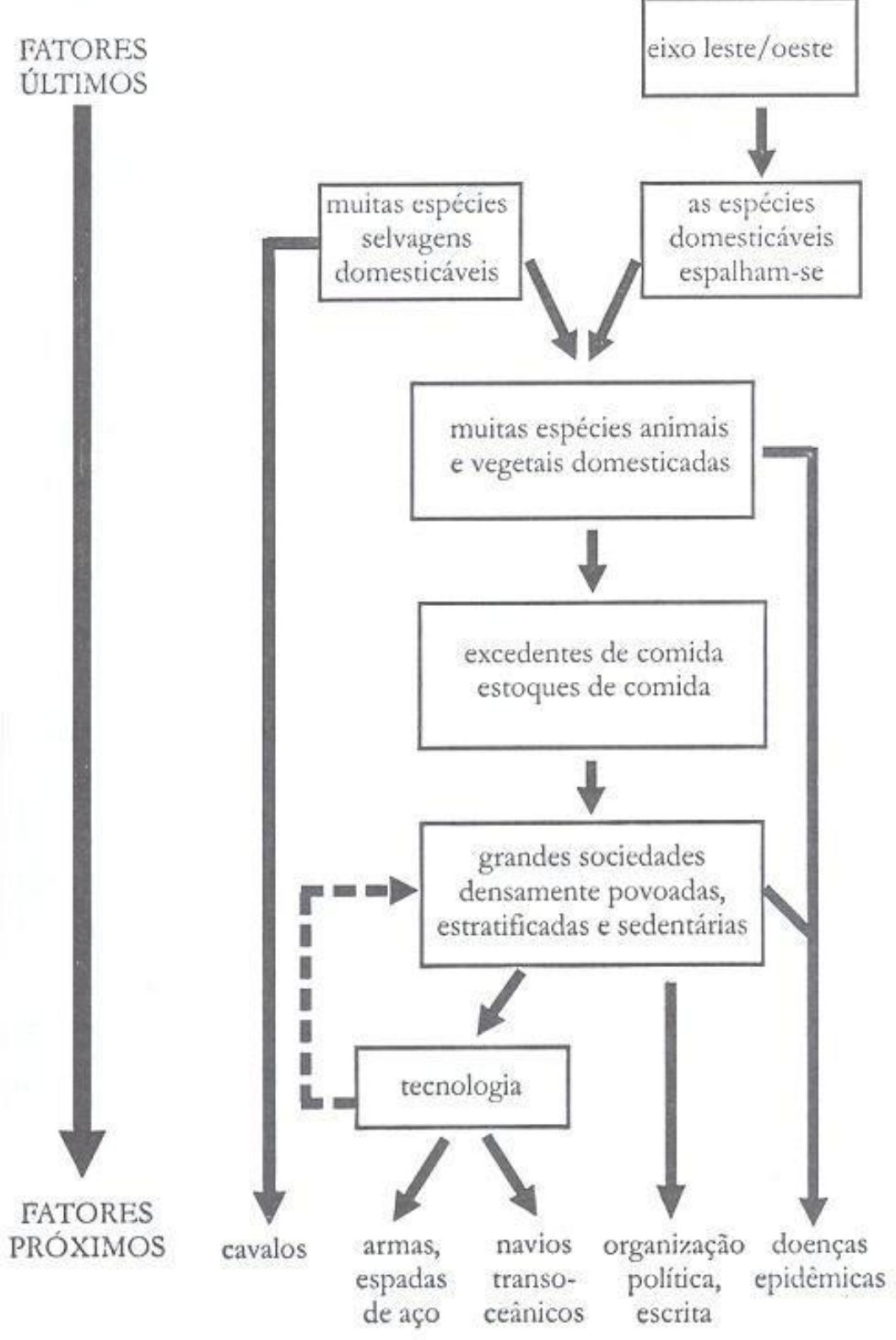

Figura 5 - "Visão esquemática das cadeias de causas que levaram aos fatores imediatos [...], permitindo que alguns povos conquistassem outros povos, a partir dos fatores fundamentais [...]." (DIAMOND, 1997, p. 85). 
Primeiro, as formas dos continentes. Segundo Jared Diamond (1997, p. 177), as direções dos eixos continentais

afetaram o ritmo da expansão da agricultura e da pecuária, e, possivelmente, também da disseminação da escrita, da roda e de outras invenções. Por isso, essa característica geográfica básica contribuiu muito para as diferenças das experiências dos nativos americanos, africanos e eurasianos nos últimos 500 anos.

Pois as espécies domesticáveis - plantas silvestres e espécies animais selvagens - disseminam-se mais facilmente no sentido latitudinal do que no sentido longitudinal.

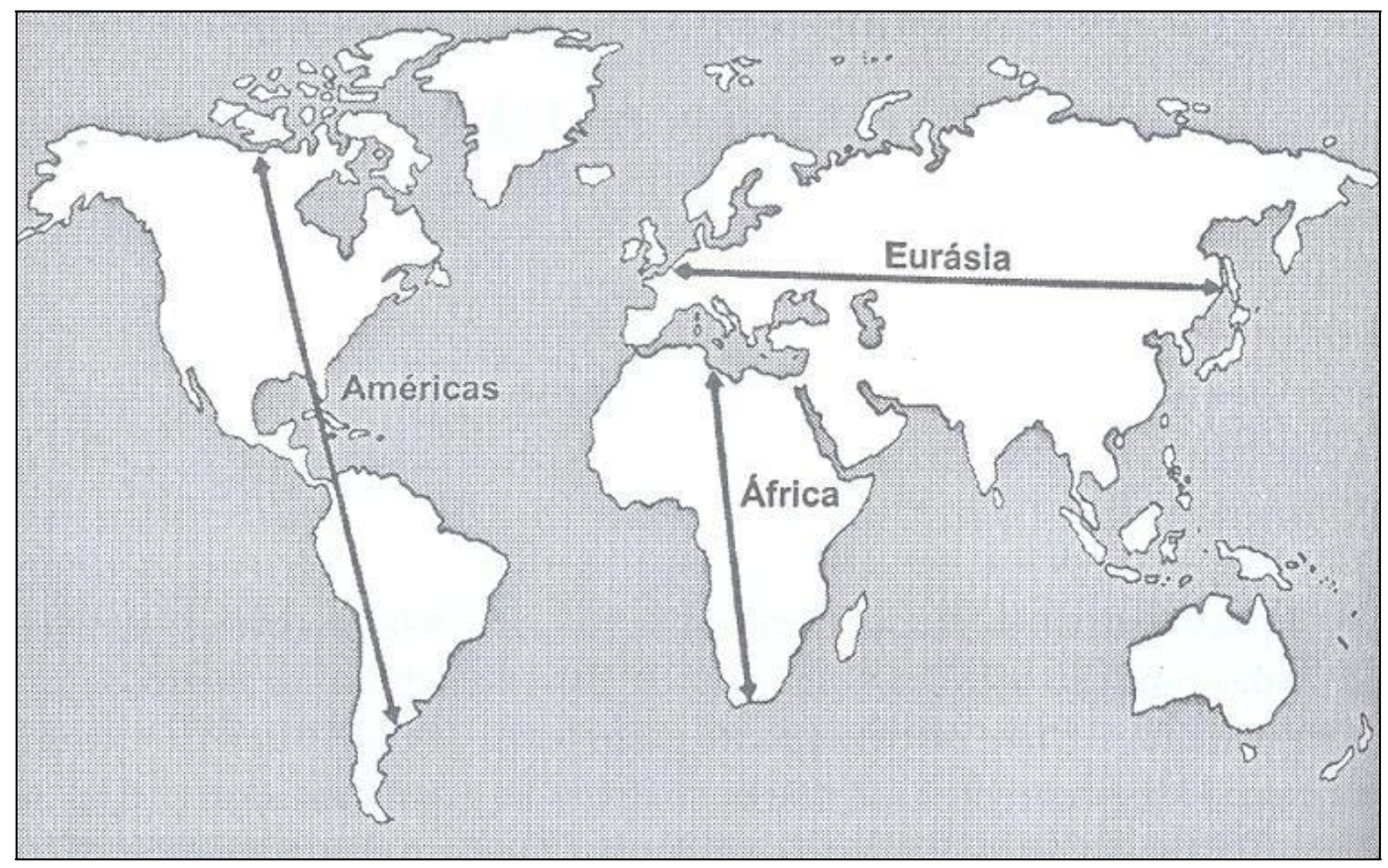

Figura 6 - Os eixos principais dos continentes segundo Jared Diamond (1997, p. 178).

$O$ argumento dos eixos continentais também joga um papel no Imperialismo ecológico de Alfred W. Crosby (1986) que figura como primeiro item na bibliografia (Leituras complementares) de Armas germes 
e aço (DIAMOND, 1997, p. 431); mas no fundo, é baseado em Charles Darwin. É verdade que esse biólogo do século XIX não é citado diretamente em Armas, germes e aço, apenas indiretamente: em duas ocasiões, referente à seleção natural (DIAMOND, 1997, p. 122 e 129). Mesmo assim, Darwin nos parece mais importante do que qualquer outra referência contida nas Leituras complementares listadas no final de Armas, germes e aço (ibidem, p. 431-440; o que em outros livros se chama de "bibliografia"). É por isso que nos permitiremos agora citar alguns trechos (largos) dele como se fossem escritos por Jared Diamond. (É por isto também que nas referências para este capítulo sobre Diamond (p. 76 de nossa dissertação) citamos, junto com Darwin, apenas aquelas poucas obras que também aparecem na bibliografia de Geografia é destino?, GALLUP; GAVIRIA; LORA, 2005, p. 157-164). Pois na essência, o que Darwin e Diamond dizem acerca dos eixos continentais é igual, e o próprio Diamond concordaria com isto. Com Darwin, estamos mais perto da fonte das idéias de Diamond (que também são relevantes para argumentos-chave em Gallup, Gaviria e Lora, 2005); e Darwin os formula mais concisamente que o próprio Diamond.

Como nos diz Darwin (2002, p. 184):

Em toda região bem povoada, a seleção natural age principalmente através da competição dos habitantes entre si; deste modo, a capacidade de enfrentar a luta pela existência e o grau de perfeição de que serão dotados os seres dependerão do padrão exigido pelas condições de vida da região. Por conseguinte, os habitantes de uma região restrita serão, via de regra, superados pelos das regiões maiores, como geralmente se verifica. Isto se deve ao fato de que as regiões maiores normalmente possuem maior número de indivíduos e de formas mais diversificadas, o que torna a competição entre eles mais acirrada, elevando o padrão de perfeição necessário à sobrevivência. 
Segundo Darwin (ibidem, p. 294), há uma preponderância das migrações provenientes do norte que se deve "à maior extensão das terras setentrionais, e ao fato de que as formas aí existentes eram em maior número, donde serem mais evoluídas que as formas meridionais, já que tiveram de enfrentar maior competição e que devem ter sofrido maiores modificações em função da seleção natural".

Segundo Darwin (ibidem, p. 276-277):

Espécies de habitat muito amplo, constituídas de grande número de indivíduos, que já derrotaram numerosos competidores antes residentes em seus atuais domínios, terão as maiores probabilidades de ocupar novos lugares, caso tenham a oportunidade de ser levadas para outros países e regiões. Em seus novos lares, estarão expostas, a novas condições e com freqüência hão de sofrer modificações e aperfeiçoamentos; assim, tornar-se-ão novamente vitoriosas, produzindo novos grupos de descendentes modificados.

Essas novas formas produzidas nas "áreas extensas, uma vez que já tenham sobrepujado numerosos competidores, serão as que irão apresentar maior dispersão, as que irão produzir a maioria das novas variedades e espécies, e as que irão desempenhar papel mais importante na história evolutiva do mundo orgânico" (ibidem, p. 112).

Para Diamond, outro aspecto de formas continentais seria, mas em detalhe, a forma da Europa: em comparação com o litoral da China (o grande concorrente potencial da Europa ao longo dos últimos milênios), o litoral da "Europa é bem mais recortado e tem mais penínsulas grandes e duas ilhas grandes" (ibidem, p. 415). A heterogeneidade geográfica relativa da Europa fez que, mesmo sendo o número de indivíduos inovadores potenciais - menor do que na China, houve uma diversidade maior de necessidades, e, portanto, inovações mais diversas. 
Quanto maior a escala temporal, tanto maior a certeza da teoria de Diamond.

Segundo Diamond, seria preciso nem de tanta nem de tão pouca difusão. Na China, por exemplo, houve demasiada facilidade de circulação, o que levou à centralização do poder de estado; na Europa, as barreiras naturais - cadeias de montanhas, formas peninsulares - evitaram uma centralização da política e permitiram a concorrência entre estados menores - e seria a concorrência que fomenta a inovação.

Além das formas dos continentes, ou influenciado por elas, encontramos o segundo "fator último": a distribuição geográfica de plantas e animais selvagens domesticáveis. Essa distribuição teria sido maior na Eurásia do que em outros continentes.

Finalmente, o terceiro conjunto de fatores "últimos" concerne às barreiras geográficas que impedem a difusão de "domesticáveis" entre os humanos. "Dependendo da localização geográfica, as sociedades diferem na rapidez com que recebem a tecnologia de outras sociedades por meio da difusão" (DIAMOND 1997, p. 257).

Essas três causas fundamentais - as formas dos continentes, a distribuição geográfica de espécies selvagens domesticáveis, as barreiras geográficas que impedem a difusão de "domesticáveis" - teriam as consequências enormes que Diamond descreve ao longo de seu livro.

(Neste momento deixamos ao leitor tirar suas próprias conclusões.) 


\subsection{David Landes; desigualdades da natureza}

David Landes, autor de vários livros bem conhecidos, é professor emérito de história e economia política na Universidade de Harvard. A única obra dele que consta na bibliografia de Geografia é destino? é $A$ Riqueza e a Pobreza das Nações (1998). No que se refere a sua vida e obra, vale o mesmo que para Jared Diamond (ver página 27).

O "geográfico" em A riqueza e a pobreza das nações de David Landes está contido no primeiro capítulo, intitulado Desigualdades da natureza (LANDES, 1998, p. 1-16); deve ser lido junto com as notas do capítulo, que se encontram nas páginas 595-597 (ibidem). (Nos capítulos posteriores, Landes adota progressivamente uma perspectiva "cultural".)

Neste primeiro capítulo, Landes começa por elogiar a Geografia: na escola primária (anos 1930), Landes conheceu uma Geografia do "ler e desenhar mapas", do tomar "conhecimento da existência de lugares, povos e costumes" (ibidem, p. 1); em universidades floresciam "as escolas de geografia econômica e cultural" (ibidem); na França da época realizaram-se estudos "de história regional" expondo "primeiro as condições materiais de vida e atividade social" (ibidem).

O eco à geografia moral e tendências racistas de certos autores levaram a repúdios da Geografia em Universidades dos Estados Unidos; Landes (ibidem, notas 3 e 4) remete a artigos de David N. Livingstone (1991), Neil Smith (1987) e Saul B. Cohen (1988) que descrevem esse fenômeno. Ellsworth Huntington, quem fez "muita pesquisa útil e reveladora" sobre "os processos pelos quais a geografia, em especial o clima, influenciou o desenvolvimento humano" (ibidem), "foi longe demais" 
(ibidem); Edmond Demolins (1901) e Arnold Guyot (1849) são mencionados neste contexto (LANDES, 1998, p. 595, notas 1 e 3 ). ${ }^{12}$

Landes diz que o problema hoje é outro:

nenhum objeto de estudo ou disciplina pode ser menos racista do que a geografia. Eis uma disciplina que, limitando-se à influência do meio ambiente, fala a respeito de tudo menos das características geradas pelo grupo. Ninguém pode ser elogiado ou censurado pela temperatura do ar, pelo excesso ou escassez das chuvas, ou pela configuração do terreno (ibidem, p. 2)

"[A] geografia está desacreditada [...] por sua própria natureza. Ela diz uma desagradável verdade, a saber, que a natureza tal como a vida, é injusta, desigual em seus favores; além disso, a iniqüidade da natureza não é facilmente remediada" (ibidem, p. 3).

Landes chega numa hipótese central do capítulo: "Num mapa do mundo em termos de produto ou renda per capita, os países ricos situamse nas zonas temperadas, sobretudo no hemisfério setentrional; os países pobres, nos trópicos e semitrópicos" (ibidem). Para sustentá-la, Landes (ibidem) cita o economista John Kenneth Galbraith (1951, p. 693; apud KAMARCK, 1976, p. 4): "[Se] demarcarmos uma faixa de uns três mil quilômetros de largura cercando a Terra no equador, não encontraremos aí nenhum país desenvolvido. [...] Em toda essa vasta área o padrão de vida é baixo, e a expectativa de vida, curta." E cita o economista Paul Streeten (1971, num livro organizado pelos economistas Dudley Seers e

\footnotetext{
${ }^{12}$ A primeira nota de rodapé do capítulo Desigualdades da natureza (LANDES, 1998, p. 595) é notável (as outras também o são): "Uma coisa em abono da escola francesa: eles estavam muito seguros de si mesmos. Assim, Edmond Demolins, no início do século: „Se a história da humanidade tivesse que começar de novo, sem qualquer mudança na superfície do mundo, repetir-se-ia de um modo geral" [DEMOLINS, 1901, p. ix]. Para uma visão cética desse interesse europeu em geografia - depreciado como treinamento em colonialismo - ver Blaut [1993], The Colonizer's Model, p. 45, nota 3" (LANDES, 1998, p. 595, nota 1).
} 
Leonard Joy, intitulado Desenvolvimento num mundo dividido): "Talvez o fato mais impressionante seja que a maioria dos países subdesenvolvidos situa-se nas zonas tropicais e semitropicais, entre o Trópico de Câncer e o Trópico de Capricórnio" (LANDES, 1998, p. 3).

No conseguinte, David Landes diferencia entre 1) "efeitos simples e diretos do meio ambiente" (LANDES, 1998, p. 4-6), e 2) efeitos indiretos/mediatos do meio ambiente (ibidem, p. 6-15).

Os "efeitos simples e diretos". Para David Landes, "a espécie humana evita os extremos" climáticos, e "o desconforto do calor excede o do frio" (ibidem, p. 4). Em clima "quente", "a lei de conservação de energia e massa" causaria em corpos humanos um problema de desperdício físico (ibidem, p. 5). "O modo mais fácil de reduzir esse problema de desperdício é não gerar calor, em outras palavras, ficar quieto e não trabalhar" (sic; ibidem). ${ }^{13}$

Efeitos indiretos. Para Landes (1998, p. 6-15), o meio ambiente afeta os seres humanos também por meio 1) de vetores de doenças (ibidem, p. 6-12) e 2) da água que afeta a agricultura (ibidem, p. 12-15).

Sobre vetores de doença:

Quanto aos efeitos diretos, o que se expôs acima é suficiente. $O$ calor, especialmente o calor que dura $o$ ano inteiro, tem uma conseqüência ainda mais deletéria: estimula a proliferação de formas de vida hostis ao homem. Os enxames de insetos fervilham quando a temperatura sobe, e os parasitas que eles abrigam amadurecem e reproduzem-se mais rapidamente. $O$ resultado é a transmissão mais rápida de doença e o

\footnotetext{
${ }^{13}$ Landes menciona que o geógrafo James M. Blaut (1993) se opõe "ideologicamente à noção de que os favores da natureza podem estar desigualmente distribuídos" (LANDES, 1998, p. 6, nota de rodapé). Landes não menciona que Blaut se refere a Collins e Roberts (1988), "que não conseguem encontrar evidência convincente de efeitos tropicais negativos" (BLAUT, 1993, p. 140, nota 43).
} 
desenvolvimento de imunidades às contramedidas. [...] As doenças causadas por insetos em climas quentes podem ser devastadoras. O inverno, portanto, apesar do que possam dizer os poetas, é o grande amigo da humanidade: o silencioso matador branco, assassino de insetos e parasitas, exterminador de pragas. Os países tropicais, exceto nas maiores altitudes, não conhecem a geada; a temperatura média no mês mais frio gira em torno dos $18^{\circ} \mathrm{C}$. Em conseqüência, fervilham de atividade biológica, em grande parte destrutiva para os seres humanos. A África subsaariana ameaça todos os que nela vivem ou dela se aproximam. (sic; ibidem, p. 6)

$\mathrm{Na}$ África tropical, as doenças e suas conseqüências distorceram, segundo Landes (ibidem, p. 8), a economia, e levaram a escravidão e conflitos de tal modo que "desencorajaram o comércio e a comunicação intertribais, e tornaram a vida urbana, com sua dependência de alimento proveniente de fora, praticamente inviável. O efeito foi retardar as trocas que impulsionam o desenvolvimento cultural e tecnológico" (ibidem). ${ }^{14}$ Landes (ibidem, p. 9-12) logo discute o papel da medicina moderna para o desenvolvimento dos trópicos. ${ }^{15}$

\footnotetext{
${ }^{14}$ Landes (1998, p. 8, nota de rodapé) contradiz Blaut (1993, p. 79-80) quem faz parte de um grupo de estudiosos que "não concordariam com esta sequencia histórica" (LANDES, 1998, p. 8). Mais na frente, Landes (ibidem, p. 596, nota 17) diz que Blaut (1993, p. 77-78) "sustenta que, até data muito recente, os climas de "latitude média" (ele prefere evitar a palavra "temperados") eram tão vulneráveis a doenças quanto os tropicais; e que os habitantes dos trópicos desenvolvem imunidades apropriadas para agentes patogênicos e parasitas. Ceteris paribus, „existe, então, um resíduo que possa ser chamado "a insalubridade inata (intrínseca?) dos trópicos"? Provavelmente a resposta é não" (LANDES, 1998, p. 596, nota 17).

${ }^{15}$ Neste contexto, Landes (1998, p. 597, nota 20) critica o historiador Gwyn Prins (1989) por ser "atento aos fracassos e erros da medicina colonial, simpático às terapias tradicionais, sem ser crédulo, quase zangado. $O$ ator está dividido entre a ciência e uma diferente espécie de "conhecimento": „por que supor que aquelas explicações consideradas largamente aplicáveis são universalmente preeminentes" ([PRINS, 1989]
} 
Landes continua sobre a água, os solos e a agricultura (ibidem, p. 12-15):

A água é um outro problema. As áreas tropicais, de modo geral, produzem em média bastante precipitação pluvial, mas a oportunidade é, com freqüência, irregular e imprevisível, as chuvaradas são tudo menos suaves. As cordas d"água são grossas, os aguaceiros torrenciais. As médias nada significam quando se vai de um extremo ao outro, de um ano, uma estação, ou mesmo de um dia para o dia seguinte. [...] Em tais regiões, o cultivo não compete facilmente com a selva e a floresta úmida: esses inestimáveis tesouros de biodiversidade favorecem todas as espécies, exceto o homem e sua limitada coleção de culturas. O resultado é uma espécie de guerra da qual tanto a natureza quanto o homem saem perdedores. [...] Depois temos as catástrofes - as tempestades e secas que acontecem uma ou duas vezes em cada década. [...] Seria um erro, entretanto, ver a geografia como destino. Seu significado pode ser reduzido ou evitado, embora invariavelmente a um certo preço. [...] (ibidem, p. 12-15)

No final do capítulo Desigualdades da natureza, Landes repete que "a lei da exaustão pelo calor aplica-se a todos, e poucas pessoas conseguem trabalhar a plena capacidade quando acaloradas e suadas" (ibidem, p. 15), e encerra o capítulo (LANDES, 1998, p. 15-16) com o seguinte depoimento do diplomata Bengali Jayantanuja Bandyopadhyaya (1983):

Em países como Índia, Paquistão, Indonésia, Nigéria e Gana, sempre me senti debilitado pelo menor esforço físico ou mental, ao passo que no Reino Unido, na França, Alemanha ou nos Estados Unidos, sempre me

p. 178)? Mas são os africanos biologicamente diferentes?" (LANDES, 1998, p. 597, nota 20). 
senti fortalecido e estimulado pelo clima temperado, não só durante longas permanências mas também nas breves estadas. E sei que todas as pessoas de regiões tropicais em visita a países temperados costumam ter uma experiência semelhante. Também vi centenas de pessoas da zona temperada sentirem-se debilitadas e exaustas nos trópicos, sempre que não se encontravam em ambiente com ar condicionado.

$\mathrm{Na}$ Índia e em outros países tropicais, observei agricultores, operários e todos os tipos de trabalhadores manuais e de escritório trabalhando em ritmo lento, com longas e freqüentes pausas para descanso. Mas na zona temperada, vi as mesmas classes de pessoas trabalhando com grande vigor e energia, e com muito poucas pausas para descanso. Conheço por experiência pessoal e pela experiência de outras pessoas de regiões tropicais na zona temperada que essa espetacular diferença em termos de energia e eficiência no trabalho não pode ser inteiramente ou mesmo principalmente devida a diferentes níveis de nutrição. (Bandyopadhyaya apud LANDES, 1998, p. 15-16)

(Neste momento deixamos ao leitor tirar suas próprias conclusões.) 


\subsection{Jeffrey Sachs; uma nova sociologia do desenvolvimento econômico}

Jeffrey Sachs, egresso da Universidade de Harvard, foi conselheiro econômico de diversos governos e na Organização das Nações Unidas, e tem alta presença nas mídias. Junto com Andrew D. Mellinger, John Luke Gallup e outros economistas, Sachs publicou diversos artigos sobre "geografia". ${ }^{16}$ Sachs preocupa-se com a pobreza e procura formas de combatê-la ${ }^{17}$ no mais alto nível da política internacional. No que se refere à vida e obra de Sachs, vale o mesmo que para Jared Diamond (ver página 27$).{ }^{18}$

\footnotetext{
16 Ver, por exemplo, Geografia e crescimento econômico (GALLUP; SACHS; MELLINGER, 1998) e Geografia e desenvolvimento econômico (GALLUP; SACHS; MELLINGER, 1998), A geografia da pobreza e da riqueza (SACHS; MELLINGER; GALLUP, 2000), Geografia, políticas econômicas e desenvolvimento regional na China (DÉMURGER et al., 2002), entre diversas outras. Grande parte desses artigos é acessível pelas páginas das instituições Social Science Research Network (http://ssrn.com/) e Research Papers in Economics (http://repec.org/).

${ }^{17}$ Agradecemos o comentário de nosso orientador.

${ }^{18}$ Lembramos apenas que o músico Bono acha que, com a ajuda de Jeffrey Sachs, "podemos ser a geração que não aceita mais que um acidente de latitude determine se uma criança vai viver ou morrer [...] Nós, do Ocidente, vamos realizar nosso potencial" (SACHS, 2005, p. 18). O ex-Secretário-Geral da Organização das Nações Unidas Ban Ki Moon apóia-se em Sachs, por exemplo, a fim de entender o conflito de Darfur (Ban Ki Moon, 2007) - que tem lugar em baixas latitudes; naquele artigo, Ban Ki Moon diz que os conflitos no Darfur, Sahel, são vinculados com a seca, a perturbação da estação das monções e, assim, com o "aquecimento do planeta provocado pelo homem" (sic; idem).
} 


\section{Dicotomia trópicos - zonas temperadas}

Na bibliografia de Geografia é destino? (GALLUP; GAVIRIA; LORA, 2005) figuram o artigo de revista Helping the World's Poorest (SACHS, 1999) e o capítulo de livro Notas para uma nova sociologia do desenvolvimento econômico (SACHS, 2002). Raciocinamos que, para os autores de Geografia é destino?, o "geográfico" essencial de Sachs esteja contido nestes dois textos. Ora, o primeiro dos dois textos aprofunda, para nós, algo que no segundo encontramos no contexto de uma "nova sociologia do desenvolvimento" mais geral. Esta "nova sociologia", por sua vez, tem uma primeira parte mais geográfica ("O papel da geografia"; ibidem, p. 73-76), outra mais cultural (baseada em Max Weber; ibidem p. 76-83), sintetizado num resto mais econômico quantitativo. Focamos no conteúdo daquela primeira parte mais geográfica (ibidem, p. 73-76).

Como diz Sachs (2002, p. 74), existem "provavelmente três grandes explicações para a persistente pobreza dos trópicos; [primeiro,] fatores agrícolas, [segundo,] fatores da saúde e [terceiro,] fatores relacionados com a mobilização de recursos científicos."

Primeiro, a zona tropical seria desfavorecida frente às zonas temperadas relativo à agricultura (ibidem, p. 74):

A agricultura tropical enfrenta diversos problemas que levam à produtividade reduzida de colheitas perenes de modo geral e de colheitas de alimentos básicos em particular: solos pobres e muita erosão e exaustão do solo nas condições de florestas úmidas; dificuldades de controle de águas e riscos de secas nos trópicos chuvosos-secos; incidência muito alta de pragas agrícolas e veterinárias; altos índices de alimentos estragados em estoque; e índices reduzidos de potencial fotossintético em regiões com temperaturas noturnas tépidas. ${ }^{19}$

\footnotetext{
${ }^{19}$ Mencione-se que "[isso] possa ser verdade, embora nas últimas décadas o Brasil venha desenvolvendo, através principalmente da Embrapa, uma tecnologia agrícola
} 
Sachs admite que haja exceções: "as regiões de solo vulcânico e aluvial, como o Delta do Nilo e Java, e vales intramontanos, onde as temperaturas noturnas são mais baixas", assim como os "planaltos tropicais densamente povoados [da] América Central, [dos] Andes, [das] regiões dos Grandes Lagos e do Rift Valley da África Oriental, e [dos] contrafortes do Himalaia" (ibidem, p. 74). Mas o resultado geral "parece ser uma limitação intrínseca da produtividade de alimentos em grandes regiões dos trópicos" (ibidem, p. 74).

Segundo, a zona tropical seria desfavorecida frente às zonas temperadas relativo à saúde nos trópicos (ibidem, p. 74-75):

O fardo das doenças infecciosas é, igualmente, mais alto nos trópicos do que nas zonas temperadas. A maioria das doenças infecciosas nas zonas temperadas é transmitida diretamente de seres humanos para seres humanos (por exemplo, tuberculose, gripe, pneumonia, doenças sexualmente transmissíveis). Nos trópicos, existem também doenças transmitidas por vetores (malária, febre amarela, esquistossomose, tripanossomíase, doença de Chagas, filariose, entre outras), nas quais animais que prosperam em clima quente, como moscas, mosquitos e moluscos, desempenham papel fundamental como hospedeiros. ${ }^{20}$

apropriada aos trópicos" (agradecemos o comentário de nosso orientador Prof. Dr. José William Vesentini).

${ }^{20}$ Mencione-se que "[isto] também possa ser verdade, embora como toda "verdade" seja transitória e histórica. A "medicina moderna" com o seu arsenal de tratamentos e remédios de fato nasceu e se desenvolveu em países que se encontram na "zona temperada", e continua a se preocupar muito mais com as doenças dos países desta zona porque eles têm maior poder aquisitivo e assim os remédios serão mais lucrativos. Mas não deixa de ser verdade que, devido a isso, possa haver mais riscos à saúde dos trabalhadores nos trópicos que nos países temperados" (agradecemos o comentário de nosso orientador Prof. Dr. José William Vesentini). 
Lembramos que Landes (1998, p. 6; ver p. 35 de nossa dissertação) diz que o calor "estimula a proliferação de formas de vida hostis ao homem".

Terceiro, a zona tropical seria desfavorecida frente às zonas temperadas relativo à mobilização de recursos científicos. Já no início de seu capítulo, Sachs diz que, para entender a distribuição desigual da renda per capita no mundo, precisar-se-ia "entender o enigma do crescimento" econômico desigual (SACHS, 2002, p. 71-72); o crescimento econômico depende do "crescimento da produtividade" (ibidem, p. 75). O aumento da produtividade, por sua vez, "é estimulado pela demanda maior e facilitado por um suprimento maior de inovadores potenciais" (ibidem, p. 75). À base da desigualdade econômica no mundo seriam, por um lado, ritmos/freqüências desiguais de inovação enquanto processo, e, por outro lado, difusão desigual de inovações. Sachs (ibidem, p. 75; num trecho que não conseguimos formular mais concisamente) faz a seguinte explicação (trans-histórica):

As regiões temperadas têm sido mais povoadas do que as regiões tropicais por pelo menos dois mil anos. Em um cálculo grosseiro, usando [dados do Atlas of World Population History de Colin McEvedy e Richard] Jones (1978), os trópicos têm abrigado cerca de um terço da população mundial nos últimos dois milênios. Se o crescimento da produtividade está relacionado com o tamanho da população e se os progressos na produtividade em uma zona ecológica não atravessam facilmente para outra zona, então pode ser vantajoso para a zona temperada ter uma parcela maior da população mundial. As duas suposições parecem realistas. O aumento da produtividade é estimulado pela demanda maior e facilitado por um suprimento maior de inovadores potenciais. Da mesma forma, avanços de produtividade na zona temperada em áreas como agricultura, saúde e construção têm menor probabilidade de ser diretamente aplicáveis às diferentes condições climáticas dos trópicos. 
Portanto, a taxa mais alta de avanço da produtividade na zona temperada talvez não seja facilmente difundida nos trópicos. $^{21}$

A segunda referência mencionada mais acima, o artigo Helping the World's Poorest ("Ajudar aos mais pobres do mundo"; SACHS, 1999), aprofundiza o argumento da mobilização de recursos científicos: as instituições de pesquisa nas áreas de agricultura e saúde, áreas sine qua non para o desenvolvimento, estariam localizadas principalmente nas zonas temperadas (Estados Unidos, Europa, Japão). Seguindo a lógica do mercado, as inovações dessas instituições serviriam para os Estados nos quais as instituições de pesquisa estão localizadas. Além disso, as inovações nas áreas de agricultura e saúde difundir-se-iam somente em latitudes parecidas, com condições de agricultura e de saúde similares. Ora, quando se trata de inovações nessas áreas que são desenvolvidas por instituições estabelecidas na zona temperada, elas só serviriam nessa zona: as instituições de alta tecnologia nas zonas temperadas fazem pesquisas para responder a necessidades da zona temperada, sem inovar na área de agricultura tropical (para melhorar a produtividade) e saúde tropical (para combater as doenças transmitidas por vetores). (Gallup, Gaviria e Lora (2005) descrevem o mesmo problema nas suas páginas 143 e 144.) Sachs (1999) conclui que seria preciso incentivar as empresas com alta tecnologia, localizadas na maioria nas zonas temperadas, a pesquisar para resolver problemas específicos da zona

\footnotetext{
21 "Sim, tem um fundo de verdade nesta conclusão, embora como já disse ultimamente o Brasil está desenvolvendo uma ótima tecnologia agrícola para os trópicos, tornando-se numa potência agrícola que está até superando os EUA. Mas de fato a tecnologia que produziu o aumento da produtividade no meio rural na Europa ou nos EUA não é aplicável ao meio tropical sem profundas adaptações. isso é apenas uma constatação e não uma forma de determinismo" (agradecemos o comentário de nosso orientador Prof. Dr. José William Vesentini).
} 
tropical. E também a promover a criação de empresas com alta tecnologia nos países tropicais. ${ }^{22}$

Para Sachs, uma das razões mais importantes da difusão de prosperidade seria "a transmissão de tecnologias e das idéias que thes são subjacentes"; e as ondas de avanço tecnológico espalhar-se-iam "mediante a difusão do comércio e do investimento externo" (SACHS 2005, p. 69-70).

As inovações, entendidas como descobertas de todo tipo de conhecimento, surgiriam das necessidades dos inovadores (potencialmente, todos nós). O crescimento da produtividade, a freqüência na qual surgem inovações, seria "relacionado com o tamanho da população" (ibidem, p. 75). Quanto maior o número de inovadores potenciais numa dada parcela da superfície terrestre, tanto maior o número de inovações. Por sua vez, a distribuição/localização/densidade das populações na superfície terrestre seria (ainda) fortemente influenciada pelas possibilidades de sustentação da vida humana que essa mesma superfície oferece, dependendo, por exemplo, de relevo, solo, hidrosfera e vegetação. Sachs (2002, p. 72) observa que as "inovações tecnológicas funcionam como uma reação em cadeia, na qual as inovações de hoje fornecem o combustível para as descobertas de amanhã”. ${ }^{23}$

A difusão das inovações dependeria da mobilidade do conhecimento assim como de características próprias da inovação que podem facilitar ou dificultar sua difusão. Avanços de produtividade numa

\footnotetext{
${ }^{22}$ Agradecemos o comentário de nosso orientador Prof. Dr. José William Vesentini.

${ }^{23}$ A "inovação não depende apenas do tamanho da população e sim de oportunidades, de um contexto social que favorece a inovação, no fundo de uma abertura - ou não repressão - a idéias inovadoras. Se fosse apenas o efetivo demográfico a China seria o berço da revolução industrial e tecnológica, mas a partir do império Ming ocorreu uma censura/repressão violenta sobre quem ousava inovar e coloca em risco o regime fechado e autoritário". (Agradecemos o comentário de nosso orientador, Prof. Dr. José William Vesentini)
} 
zona "em áreas como agricultura, saúde e construção têm menor probabilidade de ser diretamente aplicáveis às diferentes condições climáticas" de outras zonas (SACHS 2002, p. 75). Vimos que Diamond (1997) observa que as inovações na área de agricultura e saúde se disseminam com maior facilidade no sentido latitudinal que no longitudinal porque o clima muda (teoricamente) menos no sentido latitudinal. Portanto, as latitudes onde há ou houve, durante a história da humanidade, mais inovadores potenciais em agricultura e saúde, contam com mais inovações nessas áreas. Entre todas as inovações possíveis ou imagináveis, aquelas que são da área de agricultura e saúde seriam, ao mesmo tempo, os mais essenciais para a existência humana, e as que se difundem menos facilmente no sentido longitudinal. Sendo a população da Eurásia acima do trópico de Câncer maior - desde milênios - que a da África ou das Américas, houve mais inovações nessas zonas temperadas (entre China, Oriente Médio e Europa) do que em continentes com eixo norte-sul como as Américas ou a África.

Juntos com o problema da mobilização de recursos científicos, os problemas de agricultura e de saúde inerentes à zona tropical nos levam a conceber o mundo como dividido entre zona tropical e zonas temperadas. Sachs (2002, p. 75) diz o seguinte:

\begin{abstract}
A combinação de fraca produtividade agrícola e alta incidência de doenças infecciosas tem tido múltiplos efeitos adversos: uma alta proporção da população na agricultura por causa da ausência de superávit agrícola; baixo nível de urbanização; grande concentração em remotas regiões de altas altitudes (por exemplo, o altiplano andino e a região dos Grandes Lagos na África) buscando fugir dos problemas das planícies quentes e tropicais; baixa expectativa de vida e uma acumulação menor de capital humano.
\end{abstract}

Como diz Sachs (ibidem, p. 74), as "regiões temperadas são amplamente mais desenvolvidas do que os trópicos[.] $\mathrm{Na}$ lista dos trinta 
países mais ricos, só dois, Hong Kong e Cingapura - equivalentes a menos de $1 \%$ da população conjunta dos trinta países mais ricos - ficam na zona tropical". Hong Kong e Cingapura seriam "exceções que confirmam a regra. As duas cidades-estados insulares dedicam-se a indústrias e serviços. Não precisam se preocupar com baixa produtividade agrícola ou vetores portadores de doenças" (ibidem, p. 75). Sachs (ibidem, p. 76) admite que

[a] geografia é, sem dúvida, apenas um lado do enigma. Diversas regiões da zona temperada não se saíram bem, pelo menos não tanto quanto a Europa Ocidental, o Leste da Ásia (Japão, Coréia do Sul, Taiwan) e os rebentos ocidentais. As regiões retardatárias da zona temperada incluem o Norte da África e o Oriente Médio, partes do Hemisfério Sul (Argentina, Chile, Uruguai e África do Sul), e grandes partes da Europa Central e Oriental e a antiga União Soviética, que até recentemente estiveram sob regime comunista. Para compreender esses casos, temos de recorrer à teoria social.

A partir dessas três explicações, Sachs (ibidem, p. 74) conclui que não "temos, realmente, uma divisão Norte-Sul no mundo: em vez disso, temos uma divisão zona temperada - zona tropical". ${ }^{24} 25$

${ }^{24}$ Possa parecer, como já em outras ocasiões, que "forçamos" demais, deturpamos o autor para poder criticar. Esses três fatores de forma alguma implicam numa dicotomia entre os trópicos e a zona temperada. Eles podem implicar numa diferença devido ao fato de a ciência moderna e sua tecnologia terem se originado na Europa - e mais tarde nos EUA, também um país temperado. Mas não que necessariamente isso tenha ocorrido porque os climas temperados determinam o desenvolvimento da ciência ou da técnica" (agradecemos o comentário de Prof. Dr. José William Vesentini).

${ }^{25}$ Não discutimos aqui a pertinência desta regionalização frente a quaisquer outras cortes imaginárias igualmente (in)válidas da superfície do planeta, pois "nenhuma forma de regionalizar o mundo é claramente ou indiscutivelmente melhor e quase todas elas têm um fundo de verdade" (agradecemos ao nosso orientador Prof. Dr. José William Vesentini pelo comentário entre aspas). O que nos interessa é a relação que 
Sachs (1999) conclui que seria preciso incentivar empresas com alta tecnologia, tecnologia de ponta, localizadas na maioria nas zonas temperadas, a pesquisar para resolver problemas específicos da zona tropical: na área de agricultura tropical - para melhorar a produtividade - e saúde tropical - para combater malária, AIDS e tuberculose principalmente. Esses incentivos poderiam ser criados/canalizados através de organizações (financeiras) internacionais (ver SACHS, 2002 e 2005; e HOTEZ, SACHS, 2006; assim como quase todos os escritos de Sachs). Sachs (2005, p. 397) diz:

Com grande eloqüência, [Adam] Smith descreveu como a abertura do comércio marítimo entre a Europa e as Índias Orientais (sul e sudeste da Ásia) e as Índias Ocidentais (o Caribe) certamente não beneficiou as populações não européias. Em suas palavras: "Porém, para os nativos das Índias Orientais e Ocidentais, todos os benefícios comerciais que podem ter resultado [das novas rotas comerciais] foram afundados e perdidos nos terríveis infortúnios que elas ocasionaram". Smith sustentou que o problema não estava no comércio internacional em si, mas na imensa vantagem militar que a Europa tinha sobre os habitantes nativos das Américas e da Ásia: "No momento particular em que essas descobertas foram feitas, a superioridade da força era tão grande do lado dos europeus que eles puderam cometer com impunidade toda espécie de injustiça naqueles países remotos". Smith esperava pelo dia em que os habitantes das Índias Orientais e Ocidentais teriam poder suficiente para resistir a essa espoliação e achava que a globalização iria, de fato, acelerar a chegada desse dia[.]

Jeffrey Sachs cria entre latitude e nivel de bem-estar das sociedades que vivem em certas latitudes. 


\section{Fórmula matemática}

Num capítulo de livro intitulado Compreendendo os fluxos globais de capital e a distribuição global de renda: a questão é geográfica?, Paul Krugman (outro redescobridor da "geografia", como veremos no próximo capítulo) e Maurice Obstfeld (2010. p. 497-501) apontam outro aspecto da redescoberta da geografia por Jeffrey Sachs: em seu artigo "Instituições não são decisivos: efeitos diretos da geografia sobre renda per capita", Sachs (2003, p. 2) trabalha com uma fórmula estabelecida por Acemoglu, Johnson, and Robinson (2001), Easterly e Levine (2003) e Rodrik, Subramanian e Trebbis (2002). Estes economistas chegam, no que se refere à prevalência da qualidade de instituições sobre a "geografia" para a renda per capita de um país, a uma hipótese nula (ou seja, uma hipótese presumida verdadeira até que provas estatísticas sob a forma de testes de hipóteses indicariam o contrário), e por isso são criticados por Sachs. Pois Sachs considera a "geografia" como mais importante do que a qualidade de "instituições".

Essa fórmula ajuda, segundo Sachs, evidenciar que a "geografia" determine o nível de renda de um dado país mais do que as instituições desse país. Para isso, Sachs utiliza uma variável denominada "risco de malária". Com um arranjo matemático simples chegamos ao que para Jeffrey Sachs (2003, p. 4) é a "geografia":

$$
\text { Geografia }=\frac{\ln \left(Y_{i}\right)-\beta_{0}-\beta_{1} Q_{I i}+\varepsilon_{i}}{\beta_{2}^{\prime}}
$$

Em outras palavras, a geografia é igual a: o logaritmo natural da renda per capita de um dado país $i\left(Y_{i}\right)$ menos $\beta_{0}$ menos $\beta_{1}$ vezes o "índice de instituições" de um dado país (Qli) mais a margem do erro $(\varepsilon)$, tudo dividido por $\beta 2$.

Observamos que Sachs (2003, p. 10), na conclusão de seu artigo, justifica seu raciocino mediante Karl Popper (2007). Sachs diz: "Como Karl Popper nos ensinou muitos anos atrás, o fato de não rejeitar uma 
hipótese nula sobre um conjunto de dados não implica a validade da hipótese mais geral." Sachs pretendeu demonstrar, de certa maneira, que

a hipótese nula [estabelecida pelos economistas que ele pretende criticar] pode ser facilmente rejeitada usando uma variável geográfica alternativa: o risco de malária. Um modelo mais completo do desenvolvimento, no entanto, vai exigir que nós iremos além das simples especificações testadas nos três jornais analisados nesta nota. Existem boas razões teóricas e empíricas para acreditar que o processo de desenvolvimento reflete uma complexa interação entre instituições, políticas e geografia. (SACHS 2003, p. 10)

Os argumentos de Sachs foram retomados por outros economistas; os economistas Bleaney e Dimico $(2008)^{26}$ escreveram um articulo "A geografia importa: reconsiderando os efeitos da geografia sobre 0 desenvolvimento". Nesse artigo dedicado à "geografia", os economistas retomam as idéias principais do research paper de Sachs citado nos parágrafos anteriores, ampliam a fórmula com qual Sachs opera e dizem (BLEANEY; DIMICO, 2008, p. 2) que

$$
\text { Geografia }=\frac{\ln \left(Y_{i}\right)-\beta_{1}-\beta_{2} I_{i}-\beta_{3} C_{i}+\varepsilon_{i}}{\beta_{4}^{\prime}}
$$

Ou, em outras palavras, a geografia seria igual a: o logaritmo natural da renda per capita de um dado país $i\left(Y_{i}\right)$ menos $\beta_{1}$, menos $\beta_{2}$ vezes o "índice de instituições" de um dado país (li), menos $\beta_{3}$ vezes o "índice de comércio" de um dado país $(\mathrm{Ci})$, mais a margem do erro $(\varepsilon)$, tudo dividido por $\beta 4$.

(Neste momento deixamos ao leitor tirar suas próprias conclusões.)

\footnotetext{
26 Artigos afins encontram-se na página web da Universidade de Nottingham:
} http://www.nottingham.ac.uk/economics/credit/research/. Acesso em: 29 jun. 2011. 


\subsection{Paul Krugman; geografia econômica}

\section{A "nova geografia econômica"}

Para a Geografia econômica, Paul Krugman importa mais do que Landes, Diamond e Sachs. Por que Krugman, o "economista espacial", não é considerado explicitamente como "líder da redescoberta da geografia" em Geografia é destino?. Pois é ele quem ganhou o prêmio Nobel por sua "redescoberta da geografia" - que é, por sinal, título de uma conferência dele na Stockholm School of Economics em 1992, publicado no seu livro Development, Geography and Economic Theory (KRUGMAN, 1995). ${ }^{27}$ É verdade que Krugman é citado em Geografia é destino?, mas apenas marginalmente (GALLUP; GAVIRIA; LORA, 2005, p. 74). A escolha de Landes, Diamond e Sachs como "líderes da redescoberta da geografia" em vez de Krugman pode dar um problema de pesquisa.

Diz-se que a "nova geografia econômica" começou em 1991 com a publicação do livro Geografia e comércio (KRUGMAN, 1992). ${ }^{28}$ Neste livro, Krugman descreve como começou a se preocupar com a rigidez da tradicional teoria do comércio internacional (ibidem, p. 4) que, na época, ignorou quase por completo o "espaço" que deveria ser representado nos custos de transporte, nas economias de escala e na mobilidade dos factores. Sobre o uso do termo geografia, Krugman diz

$$
\begin{aligned}
& \text { O término "Localização" pareceu-me restritivo demais } \\
& \text { para a disciplina. A teoria da localização, por outra parte, } \\
& \text { pertence a um campo muito maior, a geografia } \\
& \text { econômica. Deste modo apropriei-me do término }
\end{aligned}
$$

\footnotetext{
${ }^{27}$ Agradecemos o comentário de nosso orientador Prof. Dr. José William Vesentini.

28 A "nova geografia econômica" surgiu de uma tradição chamada ciência regional (regional science) e cujo protagonista foi, desde a década de 1940, o economista Walter Isard (1956).
} 
"geografia" para descrever aquilo ao que me refiro. Suspeito que aos geógrafos não lhes gostará o que segue e pode que incluso neguem que o tipo de modelos estilizados que os economistas encontramos atrativos formem parte de sua disciplina. Apesar disso, gosto do término e por isso apropriei-me dele. (KRUGMAN, 1992, p. 5)

Vimos que para David Landes e, até certo grau, para Jeffrey Sachs, o termo "cultura" tem certa importância. Krugman evita o termo cultura; num sub-capítulo dedicado aos "atuais centro e periferia europeus" (KRUGMAN, 1992, p. 103-105), ele diz que "a parte noroeste da Europa é relativamente rica devido a causas de tipo cultural mais que de tipo geográfico" (ibidem, p. 105), ou seja, se aproxima de uma noção weberiana de cultura, mas coloca numa nota de rodapé: "Tal como Robert Solow indicou uma vez, os esforços por explicar as diferenças das rendas nacionais e das taxas de crescimento, normalmente acabam conduzindo à "erupção de sociologia amadora"' (ibidem). Para Krugman (ibidem, p. 75), "pelo imediato, os acidentes históricos continuam tendo uma importância capital".

Em 1999 foi publicado Economia espacial (FUJITA; KRUGMAN; VENABLES, 2002), obra que contém grande parte das fórmulas que constituem a "nova geografia econômica". Em Economia espacial (FUJITA; KRUGMAN; VENABLES, 2002), Fujita, Krugman e Venables fazem "geografia econômica - 0 estudo de onde a atividade econômica ocorre e por que" (ibidem, p. 15). Eles operam, como em trabalhos anteriores, com "teorias da localização", um corpo teórico que vem crescendo desde Heinrich von Thünen; sua obra é, entre outras coisas, uma continuação de teorias sobre economia urbana e ciência regional; baseia-se, particularmente, no modelo Dixit-Stiglitz de concorrência monopolista (FUJITA; KRUGMAN; VENABLES, 2002, p. 61ss). 
Derivamos de Fujita, Krugman e Venables (2002, p. 61ss) que as desigualdades socioeconômicas no mundo não são

o resultado das diferenças inerentes entre locais, mas de um conjunto de processos cumulativos, necessariamente envolvendo algum tipo de retorno crescente, por meio do qual a concentração geográfica pode se auto-reforçar. (ibidem, p. 16-17)

Fujita, Krugman e Venables preocupam-se com a "localização da atividade econômica[: as] escolhas que empresas e famílias fazem em relação a onde produzir e consumir e a como estas escolhas interagem" (ibidem, p. 11). Eles mostram,

em particular, como uma abordagem comum - que enfatiza a interação em três vias entre retornos crescentes, custos de transportes e o movimento dos fatores produtivos - pode ser aplicada a uma ampla variedade de assuntos relativos à economia regional, urbana e internacional. (ibidem)

Para isso, eles desenvolvem modelos com concorrência imperfeita e rendimentos/retornos crescentes, "difícil para os métodos econométricos tradicionais" (ibidem, p. 373). Sua análise depende

crucialmente do que talvez pudesse ser chamado de artifícios de modelagem: suposições que não refletem tanto uma visão realista de como o mundo funciona quanto um julgamento sobre o que tornará a análise dos assuntos geográficos controlável, sem causar muitos danos à relevância desta análise. (ibidem, p. 20)

Fujita, Krugman e Venables (2002, p. 371) buscam na sua obra "as conseqüências de duas idéias". Primeiro, a idéia de uma força centrípeta:

[Em] um mundo onde tanto os rendimentos crescentes como os custos de transporte são importantes, as 
conexões a jusante e a montante podem criar uma lógica circular de aglomeração. Isto é, se os outros fatores forem os mesmos, os produtores hão de querer localizarse próximo a seus fornecedores e clientes - o que significa que eles querem se localizar próximos uns aos outros. (ibidem)

As principais forças centrípetas seriam "conexões", "mercados grandes", e o "transbordamento de conhecimento e outras economias externas puras" - a "trindade de Alfred Marshall" (ibidem, p. 372). Como eles dizem, a "aglomeração - o agrupamento da atividade econômica, criada e sustentada por algum tipo de lógica circular - ocorre em muitos níveis" (ibidem, p. 15), do local ao global.

Segundo, a idéia de uma força centrífuga:

[A] imobilidade de alguns recursos - terra, certamente, e em muitos casos a mão-de-obra - age como uma força centrífuga que se opõe à força centrípeta da aglomeração. (ibidem, p. 371)

As principais forças centrífugas seriam "fatores imóveis", "aluguel de terras / transporte até o local de trabalho", e o "congestionamento e outras deseconomias puras" (ibidem, p. 372). De novo, isso ocorre em níveis/escalas do local ao global.

A "tensão entre essas forças centrífugas e centrípetas moldam a evolução da estrutura espacial da economia" (ibidem, p. 371).

Como vimos, eles criam/desenvolvem modelos, e na "modelagem econômica é natural e geralmente apropriado que o teórico simplifique os assuntos, para focalizar somente algumas das possibilidades" (ibidem, p. 372). Eles, portanto, escolheram analisar as "conexões, como uma força a favor da concentração, e à imobilidade de fatores como uma força contrária", admitindo que existam "outras escolhas possíveis" (ibidem). 
Destacamos que Fujita, Krugman e Venables (2002, p. 374) fazem a distinção entre, por um lado, uma economia positiva, e, por outro lado, uma economia normativa da geografia: Krugman, como "economista positivo", quer primeiro "uma base teórica e empírica sólida, antes de começar a especular sobre políticas de intervenções" (ibidem, p. 375). Como nos mostram Fujita, Krugman e Venables (numa parte intitulada "Implicações sobre a prosperidade", o penúltimo sub-capítulo do livro; FUJITA; KRUGMAN; VENABLES, 2002, p. 374-375), antes de buscar soluções, é preciso fazer as boas perguntas (na citação que segue, os grifos são nossos):

Alguns leitores podem ter notado certa reticência da nossa parte em relação às implicações sobre a prosperidade. Em alguns casos as conclusões são claras: por exemplo, nos modelos de especialização internacional [...] você preferiria que seu país se tornasse o centro industrializado e com altos salários do que a periferia com baixos salários. Mas em geral, tendemos a ressaltar a economia positiva, em vez da normativa, da geografia.

Existem pelo menos três motivos para essa reticência. Primeiro, sentimos que uma abordagem econômica precisa demonstrar seu poder de explicar a realidade antes de ser utilizada para prescrevê-la; para virar Marx [ou Jeffrey Sachs? N.A.] de cabeça para baixo, o ponto inicial deve ser explicar o mundo, não mudá-lo.

O segundo é um ponto mais sutil. O caso típico de políticas de intervenção se baseia em falências de mercado, especialmente em externalidades positivas ou negativas: achamos que o governo deve promover "spillovers" (transbordamentos) tecnológicos, desencorajar a poluição. A estrutura espacial de uma economia é, por conseguinte, até certo ponto o resultado de um cabo de guerra entre economias externas e 
deseconomias, entre as conexões e os spillovers de informação que fomentam a concentração, e entre o congestionamento e outras deseconomias que o desencorajam. Que externalidades importam mais? [...] A verdade é que ninguém sabe, e ninguém saberá, até que haja bastantes trabalhos empíricos sobre o assunto. Mais ou menos por definição, a pura especulação teórica não pode responder a essa pergunta.

Finalmente, estivemos envolvidos em uma parte deliberada da estrategização intelectual. $\mathrm{Na}$ história anterior das tentativas de trazer os rendimentos crescentes para a economia, mais notavelmente no caso da nova teoria do comércio, havia um pouco de pressa por parte dos intrusos em seqüestrar as novas teorias em nome das políticas intervencionistas. Mais tarde ficou aparente que isso era prematuro: as implicações relativas a políticas das novas idéias eram muito mais sutis na prática do que o neomercantilismo cru, em nome de quem elas foram invocadas. Haverá, certamente, importantes implicações relativas a políticas por parte da nova geografia econômica, mas queremos o campo em uma base teórica e empírica sólida, antes de começar a especular sobre políticas de intervenções. (FUJITA; KRUGMAN; VENABLES, 2002, p. 374-375)

Observamos ainda que Fujita, Krugman e Venables admitem que "o desenvolvimento desigual pode ter sido uma conseqüência previsível de uma crescente integração mundial" (ibidem, p. 284).

Quatro resenhas de Economia espacial (FUJITA; KRUGMAN; VENABLES, 2002), publicadas em 2001 numa seção intitulada Critical forum da revista Journal of Economic Geography, tentam confrontar idéias de geógrafos com idéias de economistas acerca deste livro: o geógrafo Eric Sheppard (2001) faz uma crítica favorável do livro; o geógrafo Peter Sunley (2001) é mais cético; os economistas David Pines (2001) e Dieter 
M. Urban (2001) entram mais no conteúdo do livro. Gary A. Dymski (1998), Ronald L. Martin (1999), Örjan Sjöberg e Fredrik Sjöholm (2002) e Ron A. Boschma e Jan G. Lambooy (1999) discutem o diálogo insuficiente entre geógrafos e economistas sobre a geografia espacial de Krugman (artigos reunidos na parte 3, Economics and economic geography, do primeiro volume de Martin e Sunley (org.), 2008, vol.1, p. 193-307). Krugman (2010, texto preparado para ser apresentado na Associação de Geógrafos Americanos) respondeu a um destes artigos (aquele de Martin, 1999): ele diz que se sente afetado por duas críticas: aquela que diz que "não há nada de novo na nova geografia econômica", e outra que diz que "o conteúdo da nova geografia econômica teria sido relevante faz cem anos, mas hoje não mais" (KRUGMAN, 2010, p. 3). À primeira critica, Krugman responde, com John Maynard Keynes e o modeling ethos, que é, sobretudo, um problema dos institucionalistas entre os economistas, e dos próprios geógrafos que refutam métodos quantitativos (ibidem, $p$. 4ss). Para responder à segunda crítica, Krugman traz o exemplo da China que mostra que são exatamente aqueles aspectos levantados por ele, ou seja, o padrão centro-periferia (costa versus interior da China) e a aglomeração da atividade econômica (clusters industriais como Wenzhou ou Yanbu Town (Nanhai)), que mostram a atualidade da nova geografia econômica (ibidem, p. 14-16). 


\section{ANOTAÇÕES CÉTICAS}

Referimo-nos à frase "o "determinismo" é uma posição mais sensata do que o ceticismo" (GALLUP; GAVIRIA; LORA, 2005, p. 16) e esboçamos algumas posições céticas que podem surgir a partir da leitura dos capítulos anteriores.

Voltamos à questão por que os autores de Geografia é destino? não consideram Krugman (defensor mais conhecido da "nova geografia econômica") ${ }^{29}$ explicitamente como "líder da redescoberta da geografia". Gallup, Gaviria e Lora (2005) criam, segundo nossa interpretação, certa tensão entre o que economistas chamam de "positivismo" (o "analisar problemas") e "normativismo" (o "buscar soluções"). Paul Krugman (FUJITA; KRUGMAN; VENABLES, 2002, p. 374) faz a distinção entre, por um lado, uma economia positiva, e, por outro lado, uma economia normativa da geografia: como vimos acima, Krugman, como "economista positivo", quer primeiro "uma base teórica e empírica sólida, antes de começar a especular sobre políticas de intervenções" (idem, p. 375; cf. página 54 de nossa dissertação). Repetimos que Krugman até poderia

\footnotetext{
${ }^{29}$ A "nova geografia econômica", parecidamente à sua predecessora, a ciência regional, é seriamente criticada por geógrafos pós-modernos (ver Trevor Barnes e David Harvey, entre outros "pensadores-chave sobre espaço e lugar" em HUBBARD; KITCHIN, 2011). Critica-se, entre outras coisas, a matematização e certo espirito positivista (PAULANI, 2007; MARACAJARO, 2009); isto nos leva à controvérsia sobre se existe uma dicotomia entre ciências humanas e naturais ou não; parece que a Geografia física se incomoda, em geral, menos do que a Geografa Humana com essa dicotomia (para citar um trabalho uspiano recente: MORAES, 2008). Aliás, Krugman seria apenas 0 representante mais conhecido desta outra "redescoberta da geografia por economistas"; diversos autores lamentam a personificação da "nova geografia econômica" com Krugman ao detrimento de tantos outros autores que contribuíram para esta vertente (SHEPPARD, 2000).
} 
contradizer os economistas do BID acima citados quando defendem políticas de acesso a mercados (GALLUP; GAVIRIA; LORA, 2005, passim): "o desenvolvimento desigual pode ter sido uma conseqüência previsível de uma crescente integração mundial" (FUJITA; KRUGMAN; VENABLES, 2002, p. 284); talvez por isso, Krugman não foi considerado como "redescobridor da geografia".

Outra razão pode ser a posição "neutra" de Krugman no que se refere a um debate no qual se opõem "geografia" e "instituições" como causas de desigualdade econômica. O assunto é discutido por Paul Krugman e Maurice Obstfeld num capítulo intitulado Compreendendo os fluxos globais de capital e a distribuição global de renda: a questão é geográfica? do seu livro Economia internacional (KRUGMAN; OBSTFELD, 2010, p. 497-501):

O que explica o fato de que alguns países enriqueceram muito, enquanto outros atraem pouco ou nenhum investimento estrangeiro e permanecem na extrema pobreza? Duas das principais escolas de pensamento sobre essa questão enfocam, de forma alternada, as características geográficas dos países e suas instituições governamentais.

Um dos principais proponentes da teoria da geografia é [...] Jared Diamond [1997] [...]. Em uma das versões da visão geográfica, aspectos do ambiente físico de um país, tais como o clima, o tipo de solo, as doenças e a acessibilidade geográfica, determinam seu desempenho econômico no longo prazo. Dessa forma, por exemplo, um clima hostil, a ausência de grandes espécies de animais facilmente domesticáveis e a ocorrência de febre amarela e malária relegaram as zonas tropicais ao segundo plano em relação às regiões mais temperadas da Europa, capazes de suportar inovações agrícolas como a rotação de culturas. Por esses motivos, Diamond 
argumenta que foram os europeus que conquistaram os habitantes do Novo Mundo e não o contrário.

Outro fator enfatizado em algumas teorias geográficas é o acesso ao comércio internacional. Os países que não têm saída para o mar e são cercados por montanhas comercializam menos com o mundo externo e portanto não se saem tão bem quanto aqueles abençoados por bons portos marítimos, rios navegáveis e eficiente malha rodoviária.

Por outro lado, aqueles que defendem as instituições governamentais como o fator decisivo para o sucesso econômico salientam a capacidade do governo de proteger os direitos de propriedade privada, fomentando dessa forma a iniciativa privada, o investimento, a inovação e, em última análise, o crescimento econômico. [...] (KRUGMAN; OBSTFELD, 2010, p. 497 e 500)

$\mathrm{Na}$ discussão sobre instituições, Krugman e Obstfeld (ibidem) remetem à obra Institutions, institutional change and economic performance do economista Douglass North (1990), ao capítulo de livro Factor endowments, institutions, and differential paths of growth among New World Economies do economista Stanley Engerman e do historiador econômico Kenneth Sokoloff (1997) (a "própria geografia desempenhava seu papel nos tipos de instituição que os colonizadores estabeleciam"; KRUGMAN; OBSTFELD, 2010, p. 500), e ao artigo The colonial origins of comparative development dos economistas Daron Acemoglu, Simon Johnson e James A. Robinson que, por maneiras diferentes, desafiam perspectivas "geográficas" sobre o desenvolvimento. Acemoglu, Johnson e Robinson (2001), particularmente, opõem-se a Jeffrey Sachs (como, aliás, apontamos no capítulo 2.3). Juntam-se a esta perspectiva institucionalista

[GLAESER; LA PORTA; LOPEZ DE SILANES; SHLEIFER, 2004.] Como reforço às explicações sobre o 
institucional em relação ao geográfico, veja [RODRIK; SUBRAMANIAN; TREBBI, 2002.] Para obter uma visão contrária, veja [SACHS, 2003.] O papel do comércio internacional no crescimento é outro foco da pesquisa corrente. Rodrik e seus coautores argumentam que a abertura ao comércio internacional não é um determinante direto primordial da renda per capita, mas leva a instituições melhores e, por meio desse canal indireto, a um aumento de renda. (KRUGMAN; OBSTFELD, 2010, p. 501)

Krugman e Obstfeld concluem seu capítulo sobre a pergunta "se os fluxos globais de capital e a distribuição global de renda são uma questão geográfica" (adaptado do título de: KRUGMAN; OBSTFELD, 2010) como segue:

Diferentemente dos pesquisadores em ciências físicas, geralmente os economistas carecem do luxo das experiências controladas. (É principalmente por isso que as conclusões inquestionáveis são tão evasivas nas ciências sociais.) (KRUGMAN; OBSTFELD, 2010, p. 501)

O economista brasileiro José Eli da Veiga (2005) aborda uma divergência parecida: aquela entre Jared Diamond, que teria uma visão materialista da história, e David Landes, com uma visão mais idealista. Veiga simpatiza mais com a visão idealista e com Douglass North quem criou a tese de que

o processo de desenvolvimento depende essencialmente da qualidade das instituições de cada sociedade. [Para] ele, as instituições são „a síntese das crenças de seu povo". Ou ainda: „a expressão concreta da mentalidade das pessoas". (VEIGA, 2005, p. 47)

"Dito assim, não há diferença entre o pensamento de North e o de David Landes, exposto no livro A riqueza e a pobreza das nações" (ibidem): a 
principal causa das diferenças de desenvolvimento seria a cultura (ibidem).

A tese de Landes e North é considerável como uma explicação idealista e subjetiva das divergências de "desenvolvimento", que, portanto, colide com explicações materialistas e objetivas dos mesmos autores (ibidem, p. 48), de modo que, "as instituições são mais resultantes do que fundamentos das relações concretas que a espécie humana vem sendo capaz de estabelecer com o grande leque de ambientes naturais que ela foi povoando e artificializando ao longo de cinqüenta milênios" (VEIGA, 2005, p. 49).

A explicação baseada em instituições de North (e Landes) opõe-se, de certa maneira, a causalidades baseadas na noção de "geografia" de Jeffrey Sachs (como dizem Krugman e Obstfeld, 2010, p. 500-501, como vimos mais acima); ela se opõe mais claramente a causalidades materialista-históricos de Jared Diamond. (Sobre a oposição entre Jared Diamond e Douglass North ver também Favareto, 2004.) Mas pode-se também dizer que North/Landes e Sachs não se opõem necessariamente, mas podem se complementar; não acreditamos que Sachs discorde seriamente de North ou de Amartya Sen (que também enfatiza a importância das instituições, particularmente do sistema escolar, dentre outros); Sachs apenas busca outras perspectivas ou fatores que vão complementar esse "peso das instituições". ${ }^{30}$

Vemos as "críticas implícitas", primeiro de Diamond, depois de Sachs.

O argumento central de Diamond é diametralmente inverso ao da dupla North/Landes, pois mostra que a cultura (conhecimento, tecnologia etc.) dos povos [...] resultou essencialmente de fatores ambientais. [...] Em síntese: vira de cabeça para baixo a tese idealista de

${ }^{30}$ Agradecemos o comentário de nosso orientador, Prof. Dr. José William Vesentini. 
North e Landes, aprofundando e atualizando aquele bom materialismo histórico cujas bases foram lançadas por Darwin e Marx. (VEIGA, 2005, p. 49)

Ou seja, Veiga cria certa relação genealógica entre Darwin, Marx e Diamond.

Concluímos apontando que os três "líderes da redescoberta da geografia" David Landes, Jared Diamond e Jeffrey Sachs operam com causalidades de pobreza diferentes e talvez incompatíveis entre si: o historiador Landes baseia-se preferencialmente em Max Weber; Diamond, como biólogo, nos leva a Darwin; e o economista Sachs, genericamente dito, é keynesiano (mesmo que sabemos, ao mais tardar desde Michel Foucault, que as genealogias de pensamento não são tão simples). Os autores de Geografia é destino? (GALLUP; GAVIRIA; LORA, 2005) não discutem as convergências ou divergências entre Darwin, Weber e Keynes.

Partimos de Geografia é destino? (GALLUP; GAVIRIA; LORA, 2005) e chegamos a autores que, cada um por sua maneira, perscruta 0 peso de condições geográficas no desenvolvimento econômico de sociedades ou regiões no mundo. A preocupação sobre o que são condições geográficas nos acompanhou ao longo da pesquisa. Vimos que para os autores de Geografia é destino?, "o "determinismo" é uma posição mais sensata do que o ceticismo" (ibidem, p. 16). Algumas resenhas do livro não se incomodam com esta premissa (HAMILTON, 2003; MAXWELL, 2003), outras sim (BURY, 2004; SLUYTER, 2005); ou seja, 
aquela controvérsia acerca do determinismo (VESENTINI, 2008) é viva. ${ }^{31}$ Esboçamos, no conseguinte, algumas idéias céticas acerca de certas "condições geográficas".

O "determinismo" mais rasteiro seria, provavelmente, representado pelos "efeitos diretos" do clima sobre o homem descritos por Landes (1998, p. 4-6; ver página 35 de nossa dissertação). ${ }^{32}$ Também é o mais facilmente refutável (para usar um termo de Karl Popper, pensador que encontramos em Jeffrey Sachs, ver página 48 de nossa dissertação): Jared Diamond contradiz Landes implicitamente quando diz:

Uma [explicação] bastante popular entre os habitantes do norte da Europa invoca o suposto efeito estimulante de seu clima frio, em contraste com o clima tropical, quente e úmido, sobre a criatividade e a energia humanas. Talvez a variação sazonal do clima nas altas latitudes apresente desafios mais variados do que o constante clima tropical. Talvez os climas frios exijam mais inventividade tecnológica para garantir a sobrevivência, porque a pessoa precisa construir uma casa quente e produzir roupas quentes para se abrigar, enquanto a que vive nos trópicos consegue sobreviver com casas mais simples e com poucas roupas. O raciocínio pode também ser invertido para que se chegue à mesma conclusão: os longos invernos nas altas latitudes deixam as pessoas com mais tempo para permanecer dentro de casa e criar.

\footnotetext{
${ }^{31}$ O geógrafo Clint Ballinger (2008) menciona Geografia é destino? ao filosofar sobre ciência; para ele, o "determinismo" não é problema em si.

${ }^{32}$ O geógrafo James Blaut dedica o capítulo 9 (intitulado David Landes: the empire strikes back) de seu livro Oito historiadores eurocêntricos (BLAUT, 2000, p. 173-199) à Riqueza e pobreza das nações (LANDES, 1998). O historiador Arruda (2000, p. 15) identifica Landes como "determinista geográfico". (Mencione-se que Jeffrey Sachs é, similarmente, contextualizado pelo geógrafo Mark Bassin (2006) numa história do determinismo geográfico, do argument from nature.)
} 
Embora já tenha sido popular, esse tipo de explicação não resiste a um exame criterioso. Como poderemos ver, os povos do norte da Europa não deram nenhuma contribuição fundamental para a civilização eurasiana até os últimos mil anos; eles simplesmente tiveram a sorte de viver em uma localização geográfica onde podiam se beneficiar dos conhecimentos (como a agricultura, a roda, a escrita e a metalurgia) desenvolvidos em partes menos frias da Eurásia. (DIAMOND, 1997, p. 22)

Isto nos leva a uma diferença essencial entre os pensamentos de Diamond e Landes, respectivamente: poderíamos tranquilamente alegar que para o darwiniano Diamond não pode haver efeitos diretos do clima sobre o ser humano (cf. SUTERMEISTER, 2011). No trecho acima, Diamond, mesmo sem querer, dá uma espécie de golpe de misericórdia aos "efeitos diretos" de Landes. A história e a diversidade de escalas temporais e espaciais parecem interferir nos "efeitos simples" de Landes: primeiro, processos históricos envolvem desenvolvimento tecnológico e sua difusão, numa certa ordem tal como: a agricultura, a roda, a escrita e a metalurgia (para isto, o meio não-vivo (clima etc.) é uma espécie de palco; cf. discussões geográficas sobre o meio); segundo, temos questões de escala: Diamond evoca temporalidades pré-históricas, o que complica 0 assunto.

Vimos que os "efeitos indiretos" de Landes envolvem saúde e agricultura (página 35 de nossa dissertação), e que Sachs raciocina de maneira similar (para agricultura, a página 40; para saúde, página 41 de nossa dissertação). Num capítulo intitulado "É verdade que na zona tropical, a agricultura é ecologicamente desfavorecida?", o geógrafo alemão Ulrich Scholz (In: GEBHARDT et al. 2007, p. 617) diz o oposto: relativo à agricultura, a zona tropical não é desfavorecida frente às zonas temperadas. Pois enquanto que na direção da linha do equador o fator que limita a agricultura pode ser a fertilidade relativamente baixa dos solos (acrissolos e ferrasolos), na direção dos trópicos de Capricórnio e 
de Câncer o fator limitante para a agricultura é (em grandes partes) a falta/escassez de água, e na direção dos polos Norte e Sul o fator limitante é a escassez de calor. Os trópicos oferecem durante o ano inteiro tanta luz, calor e água como nenhuma outra zona climática. Rendas que poderiam sazonalmente ser mais baixas são compensadas pelo fato de que nos trópicos há várias - não só uma - colheitas por ano. Sob esta perspectiva, as "exceções" de Jeffrey Sachs (regiões de solo vulcânico e aluvial, e planaltos) podem ser segundo nossa interpretação, exceções no sentido de que seu solo é excepcionalmente fértil a nível mundial. Conclusão de Scholz (idem): tanto nos trópicos úmidos como em qualquer outra zona climática do planeta opõem-se, relativo à agricultura, vantagens e desvantagens de localização.

No que se refere à saúde, lembramos (KRUGMAN; OBSTFELD, 2010, p. 501) que a visão de Sachs (e, quase necessariamente, de Landes) se opõe àquela de Daron Acemoğlu, Simon Johnson e James Robinson:

Embora [a malária e a febre amarela] fossem fatais para
os europeus desprovidos de imunidade, elas [exercem]
um efeito limitado sobre os adultos nativos que haviam
desenvolvido vários tipos de imunidade. É improvável,
portanto, que essas doenças sejam o motivo de muitos
países na África e na Ásia serem muito pobres
atualmente ... Essa noção é sustentada pelas [baixas]
taxas de mortalidade dos nativos nessas areas.
(ACEMOGLU, JOHNSON e ROBINSON apud
KRUGMAN; OBSTFELD, 2010, p. 501$)^{33}$

${ }^{33}$ Agradecemos ao nosso orientador Prof. Dr. José William Vesentini pelo seguinte comentário pessoal: "Na verdade a taxa de mortalidade dos nativos na África e partes da Ásia (Bangladesh, Paquistão, Afeganistão mesmo sem conflitos...) é extremamente alta em termos internacionais. Ela só vem diminuindo nos últimos anos devido a urbanização e a utilização de técnicas que nasceram na Europa (água encanada, rede de esgotos, vacinação em massa, saneamento de pântanos e rios, etc.)". 
Jared Diamond (1997, p. 186), por sua vez, diz:

Os animais [...] são adaptados às características climáticas relacionadas com a latitude. Nesse aspecto, somos animais típicos, como sabemos por introspecção. Alguns de nós não suportam as baixas temperaturas do inverno do norte, com seus dias curtos e seus germes característicos, enquanto outros não conseguem suportar os climas tropicais quentes com suas doenças características.

Outro aspecto sobre a "saúde" pode ser que a fome faz que as pessoas percam "sua capacidade de produzir anticorpos e de defender-se contra as agressões microbianas ou virais" (ABRAMOVAY, 1985, p. 2122). Quando a fome é causa de vulnerabilidade, é preciso estudar as causas da fome, um tema familiar à medicina e à biologia, mas também à história. Sobre a vulnerabilidade a doenças há respostas complexas (BOHLE, 2010, p. 16-23). As condições/situações de saúde dependeriam da vulnerabilidade individual e, portanto, de relações de poder e de posse, de participação política ou de mudanças nas relações entre homem e meio (ibidem); a vulnerabilidade relativa a doenças seria consequência de um conjunto de causas que geralmente teria pouco a ver com o meio nãohumano (formulação nossa; cf. BOHLE, 2010, p. 22), mas com a interação entre humanos. ${ }^{34}$

Vimos acima respostas aos "efeitos simples e diretos" de Landes e aos "efeitos indiretos" (referente a agricultura e saúde) de Landes e

\footnotetext{
${ }^{34}$ Num sub-capítulo intitulado "As consequências de uma relação conflituosa homem $\mathrm{x}$ meio: desmatamento e desertificação", José Bueno Conti (2002, p. 9) nos diz: "se de algum modo, nossas latitudes [o Brasil], atualmente, possam estar em posição de inferioridade, a culpa não é da Geografia, que nos favorece e sim da História e da Economia". O geógrafo alemão Hans-Georg Bohle (2010, p. 8) diz em seu capítulo "Geografia do desenvolvimento" que, para o mal-estar de uma sociedade, não se pode responsabilizar o meio no qual se vive. Voltamos à questão sobre relações homemmeio que, por sua vez, se desdobra em inúmeras outras questões filosóficas.
} 
retomados por Sachs. Ora, no que se refere a idéias centrais de Diamond, é menos fácil detectar problemas desde um ponto de vista cético. Pois há certo consenso sobre idéias-chave contidas em Armas, germes e aço (DIAMOND, 1997). Dois dos três "novos conjuntos de perguntas" que Samir Amin destaca no artigo Fourteen Ninety-two do geógrafo James M. Blaut (que, em outra ocasião, critica Diamond severamente; BLAUT, 2000, p. 149-172) correspondem, segundo nossa interpretação, ao que Diamond diz sobre a expansão de europeus sobre as Américas:

Para a pergunta "Por que a América foi conquistada pelos europeus e não pelos africanos ou pelos asiáticos", Blaut argumenta que a resposta deve ser procurada em termos geográficos: era mais fácil - mesmo por acaso - para chegar à costa atlântica da América a partir da Península Ibérica do que mais ao sul; era muito mais difícil para os asiáticos chegar a América através do Pacífico.

Para a pergunta "Por que a conquista foi bem-sucedida?" Blaut salienta - com razão - o fato de que a agricultura nativa norte-americana ficou 4000 anos atrás daquela do Velho Mundo, devido ao relativo isolamento do continente. (Samir Amin in: BLAUT et al., 1992, p. 83.)

Diamond simplesmente concordaria. Em outros tantos pontos, que estão à espera de análises nossas, Blaut e Diamond divergem muito, evidentemente. Lembramos que Blaut dedica o capítulo 8 (intitulado Jared Diamond: Euro-environmentalism) de seu livro Oito historiadores eurocêntricos (BLAUT, 2000, p. 149-172) a Armas, germes e aço (DIAMOND, 1997). Blaut (2000, p. 165-170) critica, por exemplo, certa arbitrariedade na comparação que Diamond faz entre as formas continentais da Europa e da China. Sobre o "segundo fator último" de Diamond, Blaut (ibidem, p. 153-164) diz que carece de verificabilidade se a distribuição geográfica de plantas e animais selvagens domesticáveis teria sido maior na Eurásia do que em outros continentes. Sobre o "terceiro fator último" de Diamond, Blaut (ibidem, p. 157) diz que as 
estepes, montanhas e desertos da Ásia Central, entre China e Europa, representariam barreiras geográficas dentro da Eurásia.

Tim Unwin (2007) critica Sachs menos por sua contribuição geográfica do que por suas intenções políticas. Unwin é conhecido por seu livro O lugar da geografia (UNWIN 1995); ele dedica um artigo intitulado Não há fim da pobreza (UNWIN 2007) ao livro de Sachs (2005) intitulado $O$ fim da pobreza; ${ }^{35}$ neste artigo, "projetado para criticar $O$ fim da pobreza de Jeffrey Sachs", Unwin "destaca em particular as dificuldades que surgem a partir do foco [de Jeffrey Sachs] na pobreza absoluta e sua receita prevista para a sua eliminação. Ele começa por salientar os pontos fortes dos argumentos de Sachs, mas sugere que estes poderiam ser temperadas por uma maior atenção à conceptualizações relativo a pobreza e aos fundamentos éticos sobre os quais os seus argumentos são baseados. Seis questões principais são posteriormente analisadas: o uso da noção de uma escada do desenvolvimento [ladder of development], sua concentração em países em vez de pessoas; sua compreensão da geografia e da história; sua relativa falta de atenção às dimensões sociais e culturais do desenvolvimento; a incapacidade dos países pobres para absorver os níveis de ajuda que ele propõe; e os danos causados pela própria sugestão de que fosse realmente possível acabar com a pobreza" (UNWIN 2007, trechos do resumo).

${ }^{35}$ Como diz Sachs no seu livro O fim da pobreza (2005, p. 398), "o progresso social deveria ser universal[.] Todas as principais figuras do [iluminismo] ... seguiam Adam Smith na crença de que o comércio global - o que hoje chamaríamos de globalização aceleraria o processo" (ibidem, p. 397). 
Na introdução, Unwin (2007, p. 929) diz:

O objetivo central deste trabalho é apresentar uma crítica à posição cada vez mais hegemônica no âmbito da comunidade mundial do desenvolvimento [global development community] que propõe que seja possível eliminar a pobreza por meio de um determinado tipo de crescimento econômico. Fazemos isso principalmente por meio de um exame do influente trabalho de Jeffrey Sachs (2005) The End of Poverty: How We Can Make It Happen In Our Lifetime (na edição estadunidense também legendado Possibilidades econômicas para o nosso tempo), mas em fazê-lo, baseia-se em um conjunto mais amplo de debates e literaturas. Meu argumento fundamental é que:

- Não é possível acabar com a pobreza.

- As tentativas de fazê-lo através da via defendida por Sachs, e outros que aderem a sua opinião, não vai resolver as condições subjacentes que causam a pobreza.

- Devemos, portanto, encorajar urgentemente aqueles responsáveis de permitir que as comunidades pobres e marginalizadas do mundo sejam capazes de melhorar suas vidas para criar e adotar alternativas a/para/contra este modelo hegemônico. (UNWIN, 2007, p. 929) 


\section{CONSIDERAÇÕES FINAIS}

Apresentamos certo geographical turn na Economia, enquanto os geógrafos estão num cultural ou num political turn: ${ }^{36}$ idéias sobre assuntos que, tradicionalmente, fazem parte da disciplina geográfica, mas que, nas décadas passadas, foram "redescobertas", de maneira variada e em momentos diversos, por autores não propriamente ligados a essa disciplina. Escritos do campo da Economia veiculam mais amplamente certos autores que aparecem, repetidamente, como "geógrafos": vários deles estão na ponta de discussões atuais na política internacional; Jeffrey Sachs, por exemplo. Esta redescoberta passa por debates sobre biologia, cultura, história, instituições; outros entram na matemática. Algumas dessas idéias encaixam-se mais facilmente no discurso da disciplina Geografia, como o debate sobre a nova geografia econômica de Paul Krugman, sobre a qual foram escritos muitos artigos no seio da Geografia econômica. Outras idéias são mais difíceis de integrar nas discussões da disciplina geográfica; as razões para isto são diversas e merecem estudos mais profundos.

Há certas idéias que representam, mais propriamente, uma redescoberta da natureza. Trata-se da controvérsia, ainda viva, entre cientistas sociais atuais sobre o determinismo geográfico, por alguns facilmente aceito, por outros totalmente refutado; algo que deve ser analisado minuciosamente. Pode-se analisá-lo desde a própria disciplina Geografia (o que implica necessariamente uma volta ao início do século $X X$ ), desde a Economia (e sua noção particular de determinismo), desde uma história da ciência ou desde uma filosofia da ciência (para ver como os argumentos se constituíram genealogicamente, por exemplo). ${ }^{37}$ Sobreexigidos com estas possibilidades, nosso objetivo para este trabalho

\footnotetext{
${ }^{36}$ Afirmação oral de Prof. Dr. Heinz Dieter Heidemann; anotações do exame de qualificação.

${ }^{37}$ Com base numa afirmação oral de Prof. Dr. Antonio Carlos Robert Moraes; anotações do exame de qualificação.
} 
foi simplesmente apresentar uma compilação das idéias que constituem aquilo que os autores de Geografia é destino? chamam de "redescoberta da geografia". 


\section{REFERÊNCIAS}

\section{Capítulo 1: Partindo de Geografia é destino?}

ALVES, Denisard Cneio de Oliveira; EVENSON, Robert; ROSENBERG, Elca; TIMMINS, Christopher. Salud, clima y desarrollo en el Brasil: Un análisis seccionado transversalmente. Rede de Pesquisa, documento em elaboração $n$. 386. Washington, D.C.: Departamento de Pesquisa do Banco Interamericano de Desenvolvimento, 2000. Disponível em:

http://www.iadb.org/res/pub desc.cfm?pub id=R-386\&Language=Spanish. Acesso em: 29 jun. 2011. [Esta obra não se destaca entre os estudos de caso fornecidos pelos Centros de Pesquisa da América Latina do BID (ver página 13 de nossa dissertação), mas colocamo-la aqui por ser contribuição uspiana.]

AZZONI, Carlos Roberto; MENEZES-FILHO, Naércio; MENEZES, Tatiane Almeida de; SILVEIRA NETO, Raul da Mota. Geografia e convergência da renda entre os estados brasileiros. Rede Latino-americana de Pesquisa, documento em elaboração n. 395. Washington, D.C.: Departamento de Pesquisa do Banco Interamericano de Desenvolvimento, 2000. Disponível em: http://www.ipea.gov.br/sites/000/2/livros/desigualdadepobrezabrasil/capitulo11.pd f. Acesso em: 29 jun. 2011. [Esta obra não se destaca entre os estudos de caso fornecidos pelos Centros de Pesquisa da América Latina do BID (ver página 13 de nossa dissertação), mas colocamo-la aqui por ser contribuição brasileira.]

BANCO INTERAMERICANO DE DESENVOLVIMENTO. Departamento de Pesquisa. Disponível em:

http://www.iadb.org/aboutus/departments/home.cfm?lang=pt\&dept id=RES.

Acesso em: 29 jun. 2011.

Acesso aos nove estudos de caso da Rede de Centros de Pesquisa da América Latina do BID (cf. página 13 de nossa dissertação):

http://www.iadb.org/res/pub List.cfm?language=Spanish\&pub type id=RNP\&ord er=Author\&st id=63. Acesso em: 29 jun. 2011.

Acesso a todos os livros da Série Fórum Latino-americano de Desenvolvimento: http://www.sup.org/browse.cgi?x=series\&y=Latin\%20American\%20Development \%20Forum. Acesso em: 29 jun. 2011.

BANCO INTERAMERICANO DE DESENVOLVIMENTO. Eduardo Lora.

[Currículum vitae, lista de publicações.] Disponível em:

http://www.iadb.org/research/researcher.cfm?au id=41. Acesso em: 29 jun. 2011.

CROSBY, Alfred W. The columbian exchange: biological and cultural consequences of 1492. Westport, CT: Greenwood Press, 1972.

Ecological imperialism: the biological expansion of Europe, 9001900. Cambridge: Cambridge University Press, 1986. 
Imperialismo ecológico: a expansão biológica da Europa, 900-1900.

São Paulo: Companhia das Letras, 1993. [Tradução que nos serviu para a redação da dissertação.]

DIAMOND, Jared M. Armas, germes e aço: os destinos das sociedades humanas. Rio de Janeiro: Record, 1997.

FAGAN, Brian. Floods, famines, and emperors: El Niño and the fate of civilizations. Nova lorque: Basic Books, 1999.

FUJITA, Masahisa; KRUGMAN, Paul; VENABLES, Anthony J. Economia espacial: urbanização, prosperidade econômica e desenvolvimento humano no mundo. São Paulo: Futura, 2002.

GALLUP, John Luke; GAVIRIA, Alejandro; LORA, Eduardo. Geografia é destino?: Lições da América Latina. São Paulo: UNESP, 2005. Disponível em inglês: http://go.worldbank.org/48GWVYCRJO. Acesso em: 29 jun. 2011.

GLEICK, James. Faster: the acceleration of just about everything. Nova lorque: Pantheon Books, 1999.

HAMILTON, Roger. Is geography destiny? IDBAmerica, mar. - abr. 2000.

Disponível em:

http://www.iadb.org/idbamerica/Archive/stories/2000/eng/APR00E/e400e3.htm. Acesso em: 29 jun. 2011. [Referência não citada na dissertação; serve apenas para ilustrar que "geografia é destino" é um tema recorrente no seio do BID.]

HARRIS, Marvin. The sacred cow and the abominable pig: riddles of food and culture. Nova lorque: Simon and Schuster, 1987.

HAUSMANN, Ricardo. Prisoners of Geography. Foreign Policy, n. 122, p. 44-53, jan./fev. 2001. Disponível em: http://www.jstor.org/stable/3183225. Acesso em: 29 jun. 2011. [Não consta em GALLUP; GAVIRIA; LORA, 2005; contém comentários bibliográficos úteis. Hausmann figura nos agradecimentos de GALLUP;

GAVIRIA; LORA, 2005, p. 14.]

HUNTINGTON, Ellsworth. Civilization and climate. New Haven: Yale University Press, 1915.

KRUGMAN, Paul. Ricardo"s difficult idea. Paper. Manchester conference on free trade. março de 1996. Disponível em:

http://web.mit.edu/krugman/www/ricardo.htm. Acesso em: 29 jun. 2011. [Não consta na bibliografia de GALLUP; GAVIRIA; LORA, 2005; na nossa dissertação, é apenas citado numa nota de rodapé para ilustrar a relevância de David Ricardo para o assunto.]

LANDES, David S. A riqueza e a pobreza das nações: por que algumas são ricas e outras tão pobres, Rio de Janeiro: Campus, 1998.

McCULLOUGH, David. The path between the seas: the creation of the Panama Canal, 1870-1914. Nova lorque: Simon and Schuster, 1977. 
McNEILL, William H. Plagues and peoples. Garden City, NY: Anchor Press, 1976.

PORTLAND STATE UNIVERSITY. John Luke Gallup. [Curriculum vitae, lista de publicações.] Disponível em: http://www.pdx.edu/econ//lgallup. Acesso em: 29 jun. 2011.

RICARDO, David. Capítulo VII: Sobre o Comércio Exterior. In:

Princípios de Economia Política e Tributação. Trad. Paulo Henrique Ribeiro Sandroni. São Paulo: Nova Cultural Ltda., 1996. p. 93-107. Disponível em: http://www.projetos.unijui.edu.br/peteconomia/David\%20Ricardo.pdf. Acesso em: 29 jun. 2011.

RIDLEY, Matt. Genome: the autobiography of a species in 23 chapters. Nova Iorque: Harper Collins, 1999.

SACHS, Jeffrey D. Helping the World's Poorest. The Economist, 352 (8132), 14 ago. 1999. Disponível em:

http://www.cid.harvard.edu/cidinthenews/articles/sf9108.html. Acesso em: 29 jun. 2011.

Notas para uma nova sociologia do desenvolvimento econômico. In: HARRISON, Lawrence E.; HUNTINGTON, Samuel P. (org.). A cultura importa. Rio de Janeiro: Record, 2002. p. 71-88.

SCHUMPETER, Joseph Alois. O processo da destruição criadora. In:

Capitalismo, socialismo e democracia. Rio de Janeiro: Fundo de cultura, 1961. p. 103-109.

SMITH, Adam. A divisão do trabalho é limitada pela extensão do mercado. In:

p. 23-28. A riqueza das nações, Volume 1, São Paulo: Martins Fontes, 2003.

STRAHLER, Alan H.; STRAHLER, Arthur N. Modern physical geography. Nova lorque: John Wiley and Sons, 1992. [Cf. em espanhol: Geografía física.

Barcelona: Omega, 1977; com várias reedições.]

UNIVERSIDAD DE LOS ANDES. Alejandro Gaviria. [Curriculum vitae, lista de publicações.] Disponível em:

http://economia.uniandes.edu.co/profesores/planta/Gaviria Alejandro. Acesso em: 29 jun. 2011.

WEINER, Jonathan. Time, love and memory: a great biologist and his quest for the origins of behavior. Nova lorque: Vintage Books, 1999.

WILLIAMS, Eric. Capitalism and slavery. Londres: Andre Deutch Limited, 1964.

WITTFOGEL, Karl. Oriental despotism: a comparative study of total power.

Nova Iorque: Vintage Books, 1981. 


\section{Capítulo 2: Os redescobridores da geografia}

\section{Capítulo 2.1: Jared Diamond; os eixos continentais}

CROSBY, Alfred W. Ecological imperialism: the biological expansion of Europe, 900-1900. Cambridge: Cambridge University Press, 1986. [Consta também nas referências de Geografia é destino? (GALLUP; GAVIRIA; LORA, 2005).]

DARWIN, Charles. Origem das espécies. Belo Horizonte: Itatiaia, 2002. [Referência que não aparece explicitamente na bibliografia (Leituras complementares) de DIAMOND, 1997.]

DIAMOND, Jared M. Armas, germes e aço: os destinos das sociedades humanas. Rio de Janeiro: Record, 1997. [Consta também nas referências de Geografia é destino? (GALLUP; GAVIRIA; LORA, 2005).]

McNEILL, William H. Plagues and Peoples. Garden City, NY: Anchor Press, 1976. [Consta também nas referências de Geografia é destino? (GALLUP; GAVIRIA; LORA, 2005).]

WITTFOGEL, Karl. Oriental despotism. New Haven: Yale University Press, 1957. [Consta também nas referências de Geografia é destino? (GALLUP; GAVIRIA; LORA, 2005).]

\section{Capítulo 2.2: David Landes; desigualdades da natureza ${ }^{38}$}

ALTMAN, Lawrence K. Researcher"s infection raises concerns for laboratory safety. New York Times, 23 ago. 1994, p. C3. Disponível em:

http://www.nytimes.com/1994/08/23/science/the-doctor-s-world-researcher-sinfection-raises-concerns-for-laboratory-safety.html. Acesso em: 29 jun. 2011.

BANCO MUNDIAL. World development report 1991: the challenge of development. Washington, D.C., 1991. Disponível em:

http://go.worldbank.org/lHF0OSLPQ0. Acesso em: 29 jun. 2011.

World development report 1994: infrastructure for development. Washington, D.C., 1994. [Consta também nas referências de Geografia é

38 Bibliografia completa de: LANDES, David. 1. Desigualdades da Natureza. In: A riqueza e a pobreza das nações: por que algumas são tão ricas e outras tão pobres. Rio de Janeiro: Campus, 1998, p. 1-16 e 595-597 (notas). 
destino? (GALLUP; GAVIRIA; LORA, 2005).] Disponível em:

http://go.worldbank.org/KMHUE61CU0. Acesso em: 29 jun. 2011.

BANDYOPADHYAYA, Jayantanuja. Climate and world order: an inquiry into the natural cause of underdevelopment. Atlantic Highlands, NJ: Humanities Press, 1983.

BLAUT, James M. The colonizer's model of the world: geographical diffusionism and eurocentric history. Nova lorque: Guilford, 1993.

COHEN, Saul B. Reflections on the elimination of geography at Harvard, 194751. Annals of the American Association of Geographers, v. 78, n. 1, p. 148151, 1988. Disponível em: http://www.jstor.org/stable/2563447. Acesso em: 29 jun. 2011.

CURTIN, Philip D. Death by migration: Europe"s encounter with the tropical world in the nineteenth century. Cambridge: Cambridge University Press, 1989.

The DEADLY hitch-hikers. The Economist, Londres, 31 out. 1992, p. 87.

DEMOLINS, Edmond. Les grandes routes des peuples, essai de géographie sociale: comment la route crée le type social. Paris, Firmin Didot \& cie, 1901. Disponível em: http://www.archive.org/details/lesgrandesroutes01demo. Acesso em: 29 jun. 2011. [Nas notas do capítulo 1 de LANDES 1998, mas não na bibliografia.]

EASTERLIN, Richard A. Industrial revolution and mortality revolution: two of a kind? Journal of Evolutionary Economics, v. 5, n. 4, p. 393-408, 1995.

Disponível em: http://dx.doi.org/10.1007/BF01194368. Acesso em: 29 jun. 2011.

ELTIS, David. Economic growth and the ending of the transatlantic slave trade. Nova lorque: Oxford University Press, 1987.

ELVIN, Mark. The pattern of the chinese past: a social and economic interpretation. Stanford: Stanford University Press, 1973. Citado em JONES, 1981 , p. 6.

FAUJAS DE SAINT-FOND, Barthélemy. Várias obras. [O autor aparece no capítulo 1 de LANDES, 1998, mas não na bibliografia.]

GALBRAITH, John Kenneth. Conditions for economic change in underdeveloped countries. Journal of Farm Economics, v. 33, n. 4, p. 689-696, 1951. Disponível em: http://www.jstor.org/stable/1233431. Acesso em: 29 jun. 2011. [Nas notas do capítulo 1 de LANDES 1998, mas não na bibliografia.]

GIBLIN, James. Trypanosomiasis control in African history: an evaded issue?

The Journal of African History, v. 31, n. 1, p. 59-80, 1990. Disponível em: http://www.jstor.org/stable/182801. Acesso em: 29 jun. 2011.

GORDON, Murray. Slavery in the Arab World. Nova lorque: New Amsterdam Press, 1987.

L'esclavage dans le monde arabe. Paris: Robert Laffont, 1987. 
GUYOT, Arnold. The earth and man: lectures on comparative physical geography in its relation to the history of mankind. Boston: Gould, Kendall and Lincoln, 1849. Disponível em:

http://www.archive.org/details/earthandmanlect03guyogoog e em http://www.archive.org/details/earthandmanlect09guyogoog. Acesso em: 29 jun. 2011. [Nas notas do capítulo 1 de LANDES 1998, mas não na bibliografia.]

The earth and man: lectures on comparative physical geography in its relation to the history of mankind. New York: Charles Scribner's Sons, 1897. [Nas notas do capítulo 1 de LANDES 1998, mas não na bibliografia.]

HARRISON, Paul. The curse of the tropics: it"s hard to make a living in hot climates. New Scientist, n. 84, p. 602-604, 1979.

HUNTINGTON, Ellsworth. Várias obras. [O autor aparece no capítulo 1 de LANDES, 1998, mas não na bibliografia. Lembramos que Civilization and climate de Huntington (1927) consta nas referências de Geografia é destino? (GALLUP; GAVIRIA; LORA, 2005).]

JONES, Eric L. The european miracle: environments, economies and geopolitics in the history of Europe and Asia. Cambridge: Cambridge University Press, 1981.

KAMARCK, Andrew M. The tropics and economic development: a provocative inquiry into the poverty of nations. Baltimore/Londres: Johns Hopkins University Press (para o Banco Mundial), 1976.

Los trópicos y el desarrollo económico: reflexiones sobre la pobreza de las naciones. Madrid: Editorial Tecnos (para o Banco Mundial), 1978. [Tradução que nos serviu para a redação da dissertação.]

LAMBERT, L. Don. The role of climate in the economic development of nations. Land Economics, v. 47, n. 4, p. 339-344, 1971. Disponível em: http://www.jstor.org/stable/3145070. Acesso em: 29 jun. 2011.

LAW, Robin. Dahomey and the slave trade: reflections on the historiography of the rise of Dahomey. The Journal of African History, v. 27, n. 2 (Special Issue in Honour of John Donnelly Fage), p. 237-267, 1986. Disponível em: http://www.jstor.org/stable/181135. Acesso em: 29 jun. 2011.

LIVINGSTONE, David N. The moral discourse of climate: historical considerations on race, place and virtue. Journal of Historical Geography, v. 17, n. 4, p. 413-434, 1991. Disponível em:

http://www.sciencedirect.com/science/article/pii/030574889190025Q. Acesso em: 29 jun. 2011.

LOVEJOY, Paul E. The impact of the Atlantic slave trade on Africa: a review of the literature. The Journal of African History, v. 30, n. 3, p. 365-394, 1989. Disponível em: http://www.jstor.org/stable/182914. Acesso em: 29 jun. 2011.

MOSS, Rowland Percy. Environmental constraints on development in tropical Africa. In: GLEAVE, M. B. (org.). Tropical African development: geographical 
perspectives. Burnt Mill, Harlow: Longmans, 1992 / New York: John Wiley, 1992, p. 50-92.

ORGANIZAÇÃO MUNDIAL DA SAÚDE. Tropical diseases. TDR-CTD/HH90.1. Genebra: Special Programme for Research and Training in Tropical Diseases, 1990. [Obra da qual Landes (1998, p. 9) tira um quadro sobre "extensão e incidência de doenças tropicais". Consta também nas referências de Geografia é destino? (GALLUP; GAVIRIA; LORA, 2005).] Citado em SATTAUR, 1990.

PRINS, Gwyn. But what was the disease? The present state of health and healing in African studies. Past \& Present, n. 124, p. 159-179, 1989. Disponível em: http://www.jstor.org/stable/650896. Acesso em: 29 jun. 2011.

RAM, Rati. Tropics and economic development: an empirical investigation. Economics Department, Illinois State University, 1996. Texto datilografado. [Sic; bibliografia de LANDES, 1998. Não consultado por nós.]

Tropics and economic development: an empirical investigation. World Development, v. 25, n. 9, p. 1443-1452, 1997. Disponível em: http://www.sciencedirect.com/science/article/pii/S0305750X97000442. Acesso em: 29 jun. 2011. [Não está na bibliografia de LANDES, 1998.]

SAH, Raaj. Priorities of developing countries in weather and climate. World Development, v. 7, n. 3, p. 337-347, 1979. Disponível em: http://www.sciencedirect.com/science/article/pii/0305750X79900615. Acesso em: 29 jun. 2011.

SATTAUR, Omar. WHO to speed up work on drugs for tropical diseases. New Scientist, v. 126, n. 1712, p. 17, 1990. Disponível em: http://www.newscientist.com/article/mg12617120.500-who-to-speed-up-work-ondrugs-for-tropical-diseases-.html. Acesso em: 29 jun. 2011.

SMITH, Adam. Parte 2 - Causas da prosperidade das novas colônias. In:_. [Investigação sobre a natureza e as causas da] Riqueza das nações. Livro IV - Os sistemas de economia política, Capítulo 7 - As colônias, p. 229-245. [Consta numa nota de rodapé do capítulo 1 de LANDES 1998, mas não na bibliografia.]

SMITH, David C. Climate, agriculture, history: an introduction. Agricultural History, v. 63, n. 2, p. 1-6, 1989. Disponível em:

http://www.jstor.org/stable/3743499. Acesso em: 29 jun. 2011.

SMITH, Neil. "Academic war over the field of Geography": the elimination of Geography at Harvard, 1947-1951. Annals of the Association of American Geographers, v. 77, n. 2, p. 155-172, 1987. Disponível em: http://www.jstor.org/stable/2562763. Acesso em: 29 jun. 2011.

STEINBECK, John. As vinhas da ira. São Paulo: Abril Cultural, 1972. [Esta obra é mencionada no capítulo 1 de LANDES, 1998, mas não na bibliografia.]

STREETEN, Paul. How poor are the poor countries? In: SEERS, Dudley; JOY, Leonard (org.). Development in a divided world. Harmondsworth: Penguin, 1971, p. 67-83. 
Artigo sobre TERAPIAS para a AIDS. New York Times, New York, 16 fev. 1997, p. 1.

Artigo sobre TRYPANOSOMIASIS. The Economist, Londres, 27 jul. 1991, p. 7475. Confira GIBLIN, 1990.

VERMA, Rupalee. Western medicine, indigenous doctors and colonial medical education. Itinerario, Leida, v. 19, n. 3, p. 130-141, 1995. Disponível em:

http://journals.cambridge.org/action/displayJournal?jid=ITI. Acesso em: 29 jun. 2011.

WADE, Nicholas. Sahelian drought: no victory for western aid. Science. v. 185, n. 4147 p. 234-237, 1974. Disponível em:

www.sciencemag.org/content/185/4147/234.full.pdf. Acesso em: 29 jun. 2011.

WALLER, Richard D. Tsetse fly in Western Narok, Kenya. The Journal of African History, v. 31, n. 1, p. 81-101, 1990. Disponível em:

http://www.jstor.org/stable/182802. Acesso em: 29 jun. 2011.

\section{Capítulo 2.3: Jeffrey Sachs; uma nova sociologia do desenvolvimento econômico}

BAN Ki Moon. A Climate Culprit In Darfur. The Washington Post, 16 de junho de 2007; p. A15. Disponível em: http://www.washingtonpost.com/wpdyn/content/article/2007/06/15/AR2007061501857.html. Acesso em: 29 jun. 2011. Versão portuguesa (O conflito de Darfur e o meio ambiente) disponível em: http://www.jornaldaciencia.org.br/Detalhe.jsp?id=48019. Acesso em: 29 jun. 2011. [Referência complementar para mostrar a relevância política de Sachs.]

BLEANEY, Michael; DIMICO, Arcangelo. Geography Matters: Reconsidering the Effect of Geography on Development. Research Paper 14/2008. Disponivel em: http://ideas.repec.org/p/not/notcre/08-14.html. Acesso em: 29 jun. 2011.

DÉMURGER, Sylvie; SACHS, Jeffrey; WOO, Wing Thye; BAO, Shu Ming; CHANG, Gene Hsin; MELLINGER, Andrew D. Geography, Economic Policy and Regional Development in China. Harvard Institute of Economic Research Paper n. 1950, 2002. Disponível em: http://ssrn.com/abstract=286672. Acesso em: 29 jun. 2011.

GALLUP, John Luke; SACHS, Jeffrey D.; MELLINGER, Andrew D. Geography and Economic Development. In: PLESKOVIC, Boris; STIGLITZ, Joseph E. (org.). World Bank Annual Conference on Development Economics 1998.

Washington, D.C.: Banco Mundial, 1999. [Consta também nas referências de Geografia é destino? (GALLUP; GAVIRIA; LORA, 2005). Conferimos:

Geography and Economic Development. National Bureau of Economic

Research. Working Paper Series, v. w6849, dez. 1998. Disponível em: http://ideas.repec.org/p/wop/cidhav/1.html. Acesso em: 29 jun. 2011.] 
GALLUP, John Luke, SACHS, Jeffrey D.; MELLINGER, Andrew D. Geography and Economic Growth. World Bank, 1998. Disponível em:

http://siteresources.worldbank.org/DEC/Resources/84797-

1251813753820/6415739-1251813951236/sachs.pdf. Acesso em: 29 jun. 2011.

HOTEZ, Peter J.; SACHS, Jeffrey D. Editorial. Science, v. 311, 17 mar. 2006.

KORNAI, Janos. The socialist system. Princeton: Princeton University Press, 1992. [Referência tida de: SACHS, 2002.]

LANDES, David S. A riqueza e a pobreza das nações: por que algumas são ricas e outras tão pobres, Rio de Janeiro: Campus, 1998. [Referência tida de: SACHS, 2002. Consta também nas referências de Geografia é destino? (GALLUP; GAVIRIA; LORA, 2005).]

MADDISON, Angus. Monitoring the world economy, 1820-1992. Paris: Organização para Cooperação Econômica e Desenvolvimento, 1995.

[Referência tida de: SACHS, 2002. Consta também nas referências de Geografia é destino? (GALLUP; GAVIRIA; LORA, 2005).]

McEVEDY, Colin; JONES, Richard. Atlas of world population history. Nova lorque: Penguin, 1978. [Referência tida de: SACHS, 2002.]

POPPER, Karl R. [Capítulo 1: Colocação de alguns problemas fundamentais. In: .] A lógica da pesquisa científica. São Paulo: Cultrix, 2007. p. 27-50. [Apenas referência implícita em SACHS, 2003.]

SACHS, Jeffrey D. Nature, nurture and growth. The Economist. 343, 12 de junho de 1997. Disponível em: http://www7.economist.com/node/91003. Acesso em: 29 jun. 2011. [Referência não citada na nossa dissertação; mas ilustra o interesse de Sachs pela "natureza".]

. Helping the World's Poorest. The Economist, 352 (8132), 14 ago.

1999. Disponível em:

http://www.cid.harvard.edu/cidinthenews/articles/sf9108.html. Acesso em: 29 jun. 2011. [Consta também nas referências de Geografia é destino? (GALLUP; GAVIRIA; LORA, 2005).]

Tropical underdevelopment. CID Working Paper No. 57, 2000.

Disponível em:

http://www.hks.harvard.edu/var/ezp site/storage/fckeditor/file/pdfs/centersprograms/centers/cid/publications/faculty/wp/057.pdf. Acesso em: 29 jun. 2011. [Referência não citada na nossa dissertação; mas ilustra o interesse de Sachs pelos "Trópicos".]

. Notas para uma nova sociologia do desenvolvimento econômico. In: HARRISON, Lawrence E.; HUNTINGTON, Samuel P. (org.). A cultura importa. Rio de Janeiro: Record, 2002. p. 71-88. [Consta também nas referências de Geografia é destino? (GALLUP; GAVIRIA; LORA, 2005).]

Institutions don"t rule: direct effects of geography on per capita income. Working Paper 9490. National Bureau of Economic Research, Cambridge MA, 2003. Disponível em: http://www.nber.org/papers/w9490. Acesso em: 29 jun. 2011. [Referência tida de: KRUGMAN; OBSTFELD, 2010.] 
O fim da pobreza: como acabar com a miséria mundial nos próximos vinte anos. São Paulo: Companhia das Letras, 2005.

SACHS, Jeffrey, MELLINGER, Andrew D. e GALLUP, John Luke. The Geography of Poverty and Wealth. Scientific American Magazine, mar. 2001. Disponível em: http://www.cid.harvard.edu/cidinthenews/articles/Sciam 0301 article.html ou http://www.surmang.org/pdf/pah2.pdf. Acesso em: 29 jun. 2011.

WEBER, Max. Economy and society. Berkeley: University of California Press, 1979. [Referência tida de: SACHS, 2002.]

YOUNG, Crawford. The African colonial state in comparative perspective. New Haven: Yale University Press, 1995. [Referência tida de: SACHS, 2002.]

\section{Capítulo 2.4: Paul Krugman; geografia econômica ${ }^{39}$}

ACEMOGLU, Daron; JOHNSON, Simon; ROBINSON, James A. The Colonial Origins of Comparative Development: an Empirical Investigation. American Economic Review, v. 91, n. 5, p. 1369-1401, dez. 2001. Disponível em: http://www.iser.uaa.alaska.edu/iser/people/Colt/econ337 f03/acemoglu institutio ns aer2001.pdf. Acesso em: 29 jun. 2011. [Referência tida de: KRUGMAN; OBSTFELD, 2010. Consta também nas referências de Geografia é destino? (GALLUP; GAVIRIA; LORA, 2005).]

BOSCHMA, Ron A.; LAMBOOY, Jan G. Evolutionary economics and economic geography. Journal of Evolutionary Economics 9, 4, 1999, p. 411-429. [Contido em MARTIN; SUNLEY, 2008, vol.1, p. 289-307.]

DIAMOND, Jared M. Armas, germes e aço: os destinos das sociedades humanas. Rio de Janeiro: Record, 1997. [Referência tida de: KRUGMAN; OBSTFELD, 2010. Consta também nas referências de Geografia é destino? (GALLUP; GAVIRIA; LORA, 2005).]

DYMSKI, Gary A. On Krugman"s model of economic geography. Geoforum, 27, 4, p. 439-452, 1998. [Contido em MARTIN; SUNLEY, 2008, vol.1, p. 210-230.]

ENGERMAN, Stanley L.; SOKOLOFF, Kenneth D. Factor endowments, institutions and differential paths of growth among new world economies: a view from economic historians of the United States. In: HABER, Stephen (org.). How Latin America fell behind. Stanford, CA: Stanford University Press, 1997.

Disponível em: http://ideas.repec.org/p/nbr/nberhi/0066.html. Acesso em: 29 jun.

39 Contém, entre outras referências, a bibliografia completa de KRUGMAN, Paul; OBSTFELD, Maurice. Compreendendo os fluxos globais de capital e a distribuição global de renda: a questão é geográfica? In: Economia internacional. Prentice Hall Brasil, 2010. p. 497-501. 
2011. [Referência tida de: KRUGMAN; OBSTFELD, 2010. Consta também nas referências de Geografia é destino? (GALLUP; GAVIRIA; LORA, 2005).]

FISCHER, Stanley. Globalization and its challenges. American Economic Review, 93, p. 1-30, maio 2003. Disponível em:

http://people.ucsc.edu/ hutch/Econ143/fischerglobal.pdf. Acesso em: 29 jun. 2011. [Referência tida de: KRUGMAN; OBSTFELD, 2010.]

FUJITA, Masahisa; KRUGMAN, Paul. The new economic geography: Past, present and the future. Papers in Regional Science 83, 2004, p. 139-164. Disponível em: http://onlinelibrary.wiley.com/doi/10.1007/s10110-003-0180-0/pdf. Acesso em: 29 jun. 2011.

FUJITA, Masahisa; KRUGMAN, Paul; VENABLES, Anthony J. Economia espacial: urbanização, prosperidade econômica e desenvolvimento humano no mundo. São Paulo: Futura, 2002. [Consta também nas referências de Geografia é destino? (GALLUP; GAVIRIA; LORA, 2005).]

GLAESER, Edward L.; LA PORTA, Rafael; LOPEZ DE SILANES, Florencio; SHLEIFER, Andrei. Do institutions cause growth? Journal of Economic Growth, 9, p. 271-303, set. 2004. Disponível em:

http://ideas.repec.org/a/kap/jecgro/v9y2004i3p271-303.html. Acesso em: 29 jun. 2011. [Referência tida de: KRUGMAN; OBSTFELD, 2010.]

GOURINCHAS, Pierre-Olivier; JEANNE, Olivier D. The elusive gains from international financial integration. Review of Economic Studies 73, p. 715-741, jul. 2006. Disponível em:

http://www.restud.org.uk/PDF/01 2006/9687 3 paper text.pdf. Acesso em: 29 jun. 2011. [Referência tida de: KRUGMAN; OBSTFELD, 2010.]

ISARD, Walter. Location and space-economy: a general theory relating to industrial location, market areas, land use, trade and urban structure. New York: Wiley, 1956. [Leitura útil para quem se interessa para a história da chamada ciência regional.]

KRUGMAN, Paul. Geografía y comércio. Barcelona: Antoni Bosch, 1992.

Geografía perdida y encontrada. In: Desarrollo, geografía y teoría económica. Barcelona: Antoni Bosch, 1995. p. 31-64.

What"s new about the new economic geography? Oxford Review of Economic Policy 14, 2, 1998, p. 7-17. [Contido em MARTIN; SUNLEY, 2008, vol.1, p. 195-209.]

The New Economic Geography, now middle-aged. Prepared for presentation to the Association of American Geographers, April 16, 2010. Disponível em: http://www.princeton.edu/ pkrugman/aag.pdf. Acesso em: 29 jun. 2011.

KRUGMAN, Paul; OBSTFELD, Maurice. Compreendendo os fluxos globais de capital e a distribuição global de renda: a questão é geográfica? In:

Economia internacional. Prentice Hall Brasil, 2010. p. 497-501. 
LUCAS, Jr. Robert E. Why doesn"t capital flow from rich to poor countries? American Economic Review 80, maio 1990, p. 92-96. Disponível em http://www.jstor.org/pss/2006549. Acesso em: 29 jun. 2011. [Referência tida de: KRUGMAN; OBSTFELD, 2010.]

MARTIN, Ronald L. The new "geographical turn" in economics: some critical reflections. Cambridge Journal of Economics 23, 1999, p. 65-91. [Contido em MARTIN; SUNLEY, 2008, vol.1, p. 231-263.]

MARTIN, Ronald L.; SUNLEY, Peter J. (org.). Economic Geography: critical concepts in the social sciences. 4 volumes. London/New York: Routledge, 2008.

NORTH, Douglass C. Institutions, institutional change and economic performance. Cambridge: Cambridge University Press, 1990. [Referência tida de: KRUGMAN; OBSTFELD, 2010.]

PINES, David. „New economic geography": revolution or counter-revolution? Journal of Economic Geography 1, 2001, p. 139-146. Disponível em: http://joeg.oxfordjournals.org/content/1/1/131.full.pdf+html. Acesso em: 29 jun. 2011.

RODRIK, Dani; SUBRAMANIAN, Arvind; TREBBI, Francesco. Institutions rule: the primacy of institutions over geography and integration in economic development. National Bureau of Economic Research, Working Paper 9305, outubro de 2002. Disponível em:

http://www.hks.harvard.edu/fs/drodrik/Research\%20papers/institutionsrule,\%205. 0.pdf Acesso em: 29 jun. 2011. [Referência tida de: KRUGMAN; OBSTFELD, 2010.]

SACHS, Jeffrey D. Institutions don"t rule: direct effects of geography on per capita income. Working Paper 9490. National Bureau of Economic Research, Cambridge MA, 2003. Disponível em: http://www.nber.org/papers/w9490. Acesso em: 29 jun. 2011. [Referência tida de: KRUGMAN; OBSTFELD, 2010.]

SHEPPARD, Eric. How „economists" think: About geography, for example. Journal of Economic Geography, 1, p. 131-136, 2001. Disponível em: http://joeg.oxfordjournals.org/content/1/1/131.full.pdf+html. Acesso em: 29 jun. 2011.

SJÖBERG, Örjan; SJÖHOLM, Fredrik. Common ground? Prospects for integrating the economic geography of geographers and economists.

Environment and Planning A 34, 2002, p. 467-486. [Contido em MARTIN; SUNLEY, 2008, vol.1, p. 264- 288.]

SUNLEY, Peter. What"s behind the models? A review of the Spatial Economy. Journal of Economic Geography, 1, p. 136-139, 2001. Disponível em:

http://joeg.oxfordjournals.org/content/1/1/131.full.pdf+html. Acesso em: 29 jun. 2011.

URBAN, Dieter M. The Spatial Economy: one new economic geographer"s view. Journal of Economic Geography, 1, p. 146-152, 2001. Disponível em:

http://joeg.oxfordjournals.org/content/1/1/131.full.pdf+html. Acesso em: 29 jun. 2011. 
VENABLES, Anthony J. New Economic Geography. Disponível em: http://www.economics.ox.ac.uk/members/tvenables/images/stories/publishedothe r/newecongeog.pdf. Acesso em: 29 jun. 2011. [Referência complementar, não citada na nossa dissertação.]

\section{Capítulo 3: Anotações céticas / Uma bibliografia complementar}

ABRAMOVAY, Ricardo. O que é fome. São Paulo: Brasiliense, 1985.

ARRUDA, José Jobson de Andrade. David Landes: um historiador desacorrentado. História \& Perspectivas, Uberlândia, n. 23, p. 9-33, jul./dez. 2000 .

BALLINGER, Clint. Determinism and the Antiquated Deontology of the Social Sciences. 2008. Disponível em:

http://opendepot.org/190/1/Ballinger, Clint, Determinism and the Antiquated D eontology of the Social Sciences.pdf. Acesso em: 29 jun. 2011.

BASSIN, Mark. Politics from Nature: Environment, Ideology, and the Determinist Tradition. In: AGNEW, John, MITCHELL, Katharyne, TOAL, Gerard. A

Companion to Political Geography. Capítulo 2. Malden, MA (Estados Unidos): Blackwell, 2006. p. 13-29.

BELLISARIO, Antonio. Resenha de: Guns, Germs, and Steel: The Fates of Human Societies by Jared Diamond. Revista Mexicana de Sociología, v. 67, n. 1, p. 214-219, jan. - mar. 2005.

BLAUT, James M. The colonizer's model of the world: geographical diffusionism and eurocentric history. New York: Guilford Press, 1993.

Eight Eurocentric historians. New York: Guilford Press, 2000.

BLAUT, James M. (org.; com contribuições de FRANK, André Gunder; DODGSHON, Robert A.; PALAN, Ronen; TAYLOR, Peter). 1492: The debate on colonialism, eurocentrism and history. Trenton NJ: Africa World Press, 1992.

BOHLE, Hans-Georg. Geografia do desenvolvimento. Revista Mercator, Fortaleza, v. 9, n. 20, set./dez 2010. Disponível em:

http://www.mercator.ufc.br/index.php/mercator/article/viewFile/510/323. Acesso em: 29 jun. 2011. [Bohle, abordando um tema relativamente parecido ao nosso, oferece-nos uma bibliografia - alemã - totalmente alheia à nossa; ou seja: não é a "geografia" que importa, mas o lugar onde ou a perspectiva a partir da qual se faz geografia.]

BURY, Jeffrey T. Book review: Is geography destiny? Lessons from Latin America. [Resenha.] Progress in Human Geography, v. 28, n. 6, p. 822-823, 
dez. 2004. Disponível em: http://phg.sagepub.com/content/28/6/822.extract. Acesso em: 29 jun. 2011.

CASTRO, Iná Elias de. Do imaginário tropical à política: a resposta da geografia brasileira à história da maldição. Scripta Nova, Barcelona, v. X, n. 18 (11), 2006. Disponível em: http://www.ub.es/geocrit/sn/sn-218-11.htm. Acesso em: 29 jun. 2011.

COLLINS, K.; ROBERTS, D. (org.). Capacity for work in the tropics.

Cambridge (England): Cambridge University Press, 1988. [Referência tida de: BLAUT, 1993.]

CONTI, José Bueno. Contribuição da geografia brasileira no entendimento do mundo tropical. Aula inaugural do Curso de Geografia da Universidade Estadual de Londrina. Londrina: UEL, 2002a

A geografia física e as relações sociedade/natureza no mundo tropical. São Paulo: Humanitas, 2002b.

EASTERLY, William. The White Man's Burden: Why the West's Efforts to Aid the Rest Have Done So Much III and So Little Good. Penguin Press, 2006.

The Elusive Quest for Growth: Economists" Adventures and Misadventures in the Tropics. MIT Press, Cambridge MA, 2002.

EASTERLY, William; LEVINE, Ross. Tropics, germs and crops: how endowments influence economic development. Journal of Monetary Economics, v. 50, n. 1, p. 3-39, jan. 2003. Disponível em:

http://ideas.repec.org/a/eee/moneco/v50y2003i1p3-39.html. Acesso em: 29 jun. 2011.

FAVARETO, Arilson. Meio-ambiente, mudança de longo prazo e modernidade elementos para uma análise em três tradições disciplinares. In: II CONGRESSO DA ASSOCIAÇÃO NACIONAL DE PÓS-GRADUAÇÃO E PESQUISA EM AMBIENTE E SOCIEDADE CAMPINAS, 26 a 29 de Maio de 2004, Campinas. Anais. Disponivel em: http://www.anppas.org.br/encontro anual/encontro2/GT/GT09/arilson.pdf. Acesso em: 29 jun. 2011.

FOUCAULT, Michel. As palavras e as coisas: uma arqueologia das ciências humanas. São Paulo: Martins Fontes, 1987. p. 61-65.

Microfísica do poder. Rio de Janeiro: Graal, 2009.

GEBHARDT, Hans; GLASER, Rüdiger; RADTKE, Ulrich; REUBER, Paul (org.) Geographie: Physische Geographie und Humangeographie. München: Spektrum, 2007. [O grande manual para graduandos em Geografia.]

HAMILTON, Roger. Por que alguns países são mais pobres do que outros: A geografia pode ser a explicação e também a solução. BIDAmérica, Revista do Banco Interamericano de Desenvolvimento, dezembro de 2003. Disponível em: http://www.iadb.org/idbamerica/index.cfm?thisid=2543. Acesso em: 29 jun. 2011. 
HUBBARD, Phil; KITCHIN, Rob. Key thinkers on space and place. London: Sage, 2011. [Oferecendo perspectivas céticas.]

MANSOR, Maracajaro. A matemática nas ciências sociais: o caso da economia. 2009. Dissertação (Mestrado) - Departamento de Economia da Faculdade de Economia, Administração e Contabilidade, Universidade de São Paulo, São Paulo, 2011. Disponível em:

http://www.teses.usp.br/teses/disponiveis/12/12140/tde-05022010-120602/ptbr.php. Acesso em: 29 jun. 2011.

MAXWELL, Kenneth. Is Geography Destiny? Lessons from Latin America. Resenha. In: Foreign Affairs, setembro/outubro de 2003. Disponível em: http://www.foreignaffairs.com/articles/59106/kenneth-maxwell/is-geographydestiny-lessons-from-latin-america Acesso em: 29 jun. 2011.

MORAES, Paulo Roberto. As áreas tropicais úmidas e as febres hemorrágicas virais: uma abordagem geográfica na área ambiental e na de saúde. São Paulo: Humanitas, 2008.

MOYO, Dambisa. Dead aid: Why aid is not working and how there is another way for Africa. New York: Farrar, Straus and Giroux; 2009.

PAULANI, Leda M. Ciência econômica e modelos de explicação científica retomando a questão. In: XXXV ENCONTRO NACIONAL DE ECONOMIA. Anais. Recife: ANPEC, 2007. Disponível em:

http://www.anpec.org.br/encontro2007/artigos/A07A171.pdf. Acesso em: 29 jun. 2011.

RESEARCH PAPERS IN ECONOMICS. Página web. Disponível em: http://repec.org/. Acesso em: 29 jun. 2011.

SHEPPARD, Eric. Geography or economics? Conceptions of space, time, interdependence, and agency. In: CLARK, Gordon L.; FELDMAN, Maryann P.; GERTLER, Meric S. (org.). The Oxford handbook of economic geography. Oxford (England): Oxford University Press, 2000, p. 199-219.

SHEPPARD, Eric; PLUMMER, Paul. Geography matters: agency, structures and dynamics at the intersection of economics and geography. Journal of Economic Geography, abril de 2006. Disponível em:

https://apps.cla.umn.edu/directory/items/publication/82687.pdf. Acesso em: 29 jun. 2011.

SLUYTER, Andrew. Is Geography Destiny?: Lessons from Latin America by John L. Gallup; Alejandro Gaviria; Eduardo Lora. [Resenha.] Annals of the

Association of American Geographers. Vol. 95, No. 1 (Mar., 2005), p. 232-236. Disponível em: http://www.jstor.org/stable/3694043. Acesso em: 29 jun. 2011.

SOCIAL SCIENCE RESEARCH NETWORK. Disponível em: http://ssrn.com/. Acesso em: 29 jun. 2011.

SUTERMEISTER, Paul. Darwin contra o determinismo geográfico / A América Latina em A geografia importa: apêndices para 'A redescoberta da 
geografia por economistas' (2011). Múnich: GRIN, 2011. Disponível em: http://www.grin.com/en/e-book/173514/. Acesso em: 29 jun. 2011.

UNIVERSIDADE DE SÃO PAULO. Biblioteca digital de teses e dissertações. São Paulo. Disponível em: http://www.teses.usp.br/. Acesso em: 29 jun. 2011.

UNWIN, Tim. El lugar de la geografía. Madrid: Cátedra, 1995.

No end to poverty. Journal of Development Studies, v. 43, n. 5, p. 929-953, 2007. Disponível em:

http://ideas.repec.org/a/taf/jdevst/v43y2007i5p929-953.html. Acesso em: 29 jun. 2011.

VEIGA, José Eli da. Os destinos das sociedades humanas. In: Do global ao local. Campinas: Armazém do Ipê (Autores Associados), 2005. p. 4750 .

VESENTINI, José William. Determinismo geográfico revivido? Reflexões a partir da resenha crítica do livro Geografia é destino? Lições da América Latina, de John Luke GALLUP, Alejandro GAVIRIA e Eduardo LORA (editora Unesp, 2007, tradução de Fernando Santos). Resenha, out. 2006. Disponível em: http://www.geocritica.com.br/destino.htm. Acesso em: 29 jun. 2011.

. Controvérsias geográficas: epistemologia e política. Confins, 2, 2008. Disponível em: http://confins.revues.org/index1162.html. Acesso em: 29 jun. 2011. 


\begin{abstract}
ANEXO: VESENTINI, José William. Determinismo geográfico revivido? Reflexões a partir da resenha crítica do livro Geografia é destino? Lições da América Latina, de John Luke GALLUP, Alejandro GAVIRIA e Eduardo LORA (editora Unesp, 2007, tradução de

Fernando Santos). Resenha, out. 2006. Disponível em:

http://www.geocritica.com.br/destino.htm. Acesso em: 29 jun. 2011.
\end{abstract}

\title{
José William Vesentini ${ }^{(*)}$
}

Publicado originalmente em 2003, em inglês, pelo BID - Banco Interamericano de Desenvolvimento -, este livro faz parte de uma série de trabalhos encomendados pelas organizações internacionais a partir dos anos 1990 que procuram explicar quais são os entraves para o desenvolvimento nas regiões pobres do globo. Neste caso, a América Latina é objeto de um estudo que procura investigar qual seria o papel da geografia no subdesenvolvimento desta parte do continente.

Para entendermos melhor o porquê deste trabalho, que na verdade foi realizado a pedido e com financiamento dessa organização internacional sediada em Washington, temos que recordar que a partir das últimas décadas do século XX inúmeras pesquisas demostraram que o desenvolvimento econômico e social, principalmente o sustentável pensando-se, evidentemente, não apenas em sustentabilidade ambiental, mas também cultural, social, econômica e por aí afora - não se explica tão somente por fatores históricos e principalmente econômicos, os únicos mencionados nas teorias tradicionais fossem elas liberais, neoliberais, marxistas, estruturalistas ou keysenianas. Os fatores ou processos culturais passaram a ser revalorizados, tendo ocorrido uma retomada embora de forma ampliada e adaptada às novas condições - do insight weberiano sobre as relações entre a ética calvinista e o espírito do capitalismo. Também determinados traços políticos (estabilidade, boa governança, baixo grau de corrupção, transparência, democracia enfim) e institucionais (bom sistema judiciário, com estabilidade institucional que garanta os contratos; sistema escolar eficiente, que forme uma força de trabalho qualificada e seja uma alavanca para a pesquisa científica e tecnológica; legislação que favoreça a inovação tecnológica e o empreendedorismo; etc.) foram estudados como causas do maior ou menor desenvolvimento deste ou daquele Estado nacional. E a geografia - ou melhor, as chamadas "condições geográficas" (localização absoluta e principalmente relativa, clima, solos, geodemografia, grau de urbanização, disponibilidade de recursos naturais, etc.) -, antes tão negligenciada, também passou novamente a ser considerada como um dos elementos que favorecem ou dificultam o desenvolvimento de uma região ou de um 
país. Nesse sentido, este trabalho procurou perscrutar o peso das condições geográficas no escasso desenvolvimento latino-americano (em comparação com a América Anglo-saxônica) e também nas desigualdades regionais dentro da América Latina ou até mesmo no interior de determinados países como o Brasil, o México, a Bolívia, a Colômbia e o Peru, que foram objetos de análises nesta obra.

Em primeiro lugar, devemos tecer elogios a este resgate da geografia pelos economistas, com uma revalorização (depois de inúmeras décadas de ostracismo!) das condições geográficas como um dos fatores determinantes do desempenho histórico-econômico de uma sociedade. Um resgate que vem se expandindo desde o final dos anos 1980 - os economistas estão descobrindo a natureza e redescobrindo/revalorizando a economia espacial e em particular a geografia econômica - e conta com nomes de peso tais como o prêmio Nobel Paul Krugman, o antigo expoente da "escola de Chicago" (e idealizador do "modelo chileno" de desenvolvimento, além de eterno candidato àquele referido prêmio) Jeffrey Sachs e inúmeros outros ${ }^{(1)}$. Os autores deste livro estranhamente deixaram de lado as obras de Krugman (com exceção de um trabalho em coautoria com Fujita e Venables, mencionado na nota 1, mas que não é a sua mais importante contribuição para este tema) e utilizaram bastante as de Sachs (na verdade o grande inspirador deste estudo) e também o volumoso livro de Landes ${ }^{(2)}$, um especialista em história e economia política da Universidade de Harvard, que, apesar de sua ênfase na cultura sob a inspiração das ideias de Weber, procurou levar em consideração as condições geográficas para explicar o atraso de algumas nações em comparação com os atuais países desenvolvidos.

Entretanto, malgrado as boas intenções este estudo ficou muito limitado pela quase total ausência de uma bibliografia geográfica, de pesquisas de fato geográficas e atuais, para alicerçar as diferenças espaciais entre países e entre regiões dentro de um mesmo território nacional. Os autores são três economistas que praticamente nada entendem de geografia e que, embora imbuídos de grande dose de boa vontade, utilizaram um material em geral ultrapassado, salvo raras exceções: noções sobre clima dos anos 1950, uma visão extremamente pobre e compartimentada das "condições geográficas", na verdade de apenas algumas delas, com cada elemento (localização, clima, solos, disponibilidade de água e de outros recursos naturais, incidência doenças tropicais, condições demográficas, grau de urbanização) visto e ponderado de forma totalmente isolada como se eles não interagissem, não formassem conjuntos ou sistemas tal como aparece nos trabalhos dos geógrafos. O único geógrafo importante mencionado foi Jared 
Diamond com o seu livro Armas, germes e aço, mas o problema é que ele é totalmente inadequado para este tipo de inquérito na medida em que trabalha com uma duração temporal extremamente longa, de milhares de anos, analisando o declínio ou a permanência de civilizações milenares (sempre em função de suas relações com o meio ambiente) e nunca diferenças regionais do nosso presente. Ademais, esse biogeógrafo norteamericano realizou pesquisas que, conquanto tenham um enorme valor, enfocaram sociedades tradicionais, pré-industriais e com tecnologia em geral rudimentar, algo bem diferente do Brasil ou do México dos nossos dias.

A metodologia deste estudo é comparativa e no fundo simples: cada fator é isolado em sua forma numérica (com tabelas), gráfica ou cartográfica e visto em comparação com alguns índices de desenvolvimento econômico ou de bem estar. Por exemplo, usa-se um mapa da América Latina dividida em ecozonas (com base em Köppen e Geiger: trópicos úmicos, trópicos de monção, temperado úmido, estepe, deserto, altitudes elevadas, etc.) e se sobrepõe a mapas ou gráficos desta mesma região (ou partes dela) de renda per capita, de PIB per capita, de densidade demográfica, de produção agrícola por trabalhador, de incidência de malária e de alguns outros indicadores. Ou então se analisa a correlação entre renda per capita e maior ou menor incidência de malária ou de outras doenças tropicais, entre altitude e PIB per capita e assim sucessivamente. Tudo bem que esse método leve a determinadas conclusões relativamente interessantes, tais como que em geral (existem exceções) as áreas temperadas da América Latina são mais desenvolvidas (isto é, possuem índices de renda per capita ou de IDH superiores à média da região) que as tropicais e principalmente que as equatoriais, ou que os países e regiões mais urbanizados têm índices de desenvolvimento econômico superiores aos menos urbanizados. O problema é que tudo isso é algo banal e já conhecido muito antes deste trabalho. Além disso, são constatações que não explicam nada, apenas descrevem correlações simples sem perceber que elas podem ter sido ocasionadas por determinados processos históricos complexos (nos quais inúmeros fatores tiveram o seu peso relativo) e não por qualquer tipo de imposição da natureza ou das "condições geográficas". Os avanços da medicina desde pelo menos o século XIX, por exemplo, foram feitos basicamente nas áreas temperadas e deixaram meio de lado (na medida em que a expectativa de lucros é bem inferior) as pesquisas sobre certas doenças tropicais que tanta mortalidade (ou às vezes baixa produtividade do trabalho) ocasionam na África e em outras áreas tropicais e principalmente equatoriais. E o maior desenvolvimento comparativo da 
Argentina, do Uruguai e do Chile, ou dentro do México da porção de maior altitude (que os autores incluem nos climas temperados) em comparação com as zonas de menor altitude (e climas mais quentes), podem ser e já foram explicados de forma mais apropriada pelas características da colonização: os europeus que vieram para povoar (e não apenas explorar determinadas riquezas com vistas ao mercado europeu) evidentemente que preferiam as áreas menos quentes não porque isso seja uma característica inata ou "natural" do ser humano e sim porque eram europeus e tinham um modo de vida (e uma tecnologia) mais apropriado para as áreas com estações do ano definidas e com invernos mais frios. Quanto à influência do maior grau de urbanização para o crescimento econômico, o livro num certo sentido coloca o carro na frente dos bois, ou seja, toma como causa algo que é consequência, pois todo mundo sabe, após inúmeras pesquisas que remontam ao século XIX, que é o desenvolvimento da economia, notadamente a industrialização, que ocasiona a urbanização e não o inverso.

O seguinte trecho do livro ilustra bem a sua essência:

"Fatores geográficos explicam grande porção da diferença de crescimento entre a América Latina e os países industrializados, mas não entre a América Latina e o Leste da Ásia. Os países industrializados contam com fatores geográficos físicos e humanos mais favoráveis, e cada um dos quais explica cerca de um terço da diferença de crescimento. As principais vantagens dos países industrializados derivam do fato de eles estarem localizados em zonas temperadas e terem índices mais elevados de urbanização. A América Latina e o Leste da Ásia têm características geográficas semelhantes, e apenas uma pequena fração da diferença de crescimento entre as duas regiões pode ser atribuída à geografia. (...) Esse ponto é crucial porque ele reforça o argumento de que geografia não é destino e que políticas e instituições adequadas conseguem compensar seus efeitos adversos." (pg. 79)

Acredito que aí está todo o espírito do trabalho, pois resume a sua ideia central. Qual seria ela? A de que as chamadas "condições geográficas" exercem uma influência, às vezes maior (como na América Latina) e por vezes menor (como no Leste da Ásia, isto é, países tropicais ou equatoriais como Cingapura que se tornaram desenvolvidos), mas que em última instância "geografia não é destino". Sem dúvida que não! Essa afirmativa é corretíssima. Por sinal, nada é destino: nem a história, nem a economia, nem a cultura e tampouco a biologia. Se a história fosse inexorável, inescapável, Cingapura não seria hoje um país desenvolvido, pois afinal também foi uma colônia de exploração e até os 
anos 1960 era tido como um dos países com maior grau de corrupção do mundo, além da pobreza de grande parte da população. E se a economia fosse destino, a outrora paupérrima China não estaria caminhando para ser a maior economia mundial; e por outro lado, países vistos como ricos e poderosos no passado, como Portugal e Espanha, tornaram-se praticamente subdesenvolvidos, só conseguindo se reerguer devido à unificação europeia - ou seja, em função, principalmente (mas não apenas), de sua localização relativa. Sequer a cultura é destino: países católicos se desenvolveram (França, Itália) enquanto que inúmeros protestantes ficaram para trás (Ruanda, Botswana, Nigéria, Suriname, Guiana, São Cristóvão e Nevis e inúmeros outros); e a propalada melhor adaptação da cultura confucionista para o desenvolvimento capitalista (tese em moda nos anos 1970 devido ao enorme "arranque" da economia japonesa no período) também é algo duvidoso, pois além da atual (desde os anos 1990) e grave crise do Japão, praticamente uma estagnação econômica que perdura por duas décadas, a China só conseguiu de fato decolar quando deixou de lado suas tradições e passou a imitar o exemplo - e a tecnologia - dos Estados Unidos e dos países europeus. Quanto à biologia, é desnecessário dar algum exemplo de que não é destino, ou seja, não determina o desenvolvimento de uma sociedade: há tempos que o racismo deixou de ser levado a sério nos meios científicos.

Seria este livro determinista? Um colega professor universitário de geografia humana fez essa afirmação peremptória (a de que o livro contém um determinismo rasteiro), mas não vou mencionar o nome porque foi apenas uma afirmação verbal num bate papo informal e não uma análise mais aprofundada em algum texto. Em todo o caso, acredito que não, isto é, que não é uma obra determinista, embora contenha inúmeras ideias banais e até simplistas. Mas para explicar isso é necessário definir precisamente 0 que estamos entendendo por determinismo, ou melhor, determinismo geográfico.

Cabe distinguir determinismo científico ou epistemológico dos demais determinismos: o econômico, o geográfico, o histórico, o cultural, o sexual, o biológico, etc. Determinismo científico, ou o princípio do determinismo tal como preferem inúmeros autores [dentre os quais Einstein, Popper e Hawking], é algo irreprochável e fundamental para a ciência moderna. É a tese segundo a qual tudo pode ser explicado objetiva e racionalmente em termos de causas e consequências. Não de forma simplista e sim complexa. Por exemplo: as causas podem ser (e geralmente são) múltiplas e até probabilísticas, e nunca uma só como imagina pensamento unilateral que, levado aos extremos, gera os determinismos particulares. $E$ as consequências ou efeitos podem virar 
causas e vice-versa (3). Mas existem causas e efeitos ou, em outras palavras, encadeamento de fatores ou de processos que interagem. Esse é o princípio do determinismo, aceito pelos físicos, químicos, biólogos, teóricos da epistemologia, etc., que fundamenta a ciência moderna desde pelo menos Galileu Galilei no século XVII. Apesar do nome em comum, ele não deve ser identificado com os determinismos particulares. Estes são condenáveis, são interpretações equivocadas, no fundo exageros ou visões unilaterais que só veem uma causa unívoca como determinante de um fenômeno, por via de regra o caráter ou as características de uma sociedade. É o caso, por exemplo, de encarar as chamadas "condições geográficas", especialmente o clima, como definidor do tipo de sociedade e da sua dinâmica. Este é o determinismo geográfico, tão em voga até pelo menos o século XVIII e que não deve ser confundido, como boa parte dos geógrafos ainda faz, com uma pretensa "escola determinista" (que nunca existiu, convém realçar) capitaneada por Ratzel (4). Podemos ainda falar num determinismo histórico, muito comum entre certos marxistas, que consiste em enxergar a história como algo inapelável e determinante, que explica e decide o futuro de tudo. Assim como também existe o determinismo sexual (a sexualidade seria o determinante de todo o comportamento humano, algo comum em certa simplificação da psicanálise), ou o econômico (atitude que vê a economia como uma panaceia que determina tudo numa sociedade: a cultura, os mitos, a tecnologia, as relações com a natureza, as relações sociais, a sexualidade e por aí afora) e inúmeros outros, sendo que o mais recente deles é o genético.

Este livro não é determinista no sentido estreito do termo, ou seja, não professa um determinismo geográfico na medida em que os autores não endossam a tese que geografia é destino, que as condições geográficas explicam todas ou quase todas as diferenças internacionais e inter-regionais de desenvolvimento. Eles apenas afirmam que "a geografia importa", isto é, que ela tem o seu peso, embora maior em certas regiões (sem nunca ser algo inexorável ou inescapável) e menor em outras nas quais as instituições políticas e sociais (incluindo-se aqui, evidentemente, a tecnologia) mais eficientes conseguem vencer as "limitações impostas pelo meio ambiente". Isso não é determinismo geográfico, é apenas o estudo - embora meio capenga ou limitado - de uma das variáveis que influem nessas desigualdades, ou melhor, de algumas variáveis tais como o clima, a altitude, a disponibilidade de recursos naturais, a urbanização e a maior ou menor incidência de certas doenças ligadas ao meio ambiente. É bom deixar claro que os autores não afirmam que só a geografia importa, ou que ela importa antes de tudo. E não se pode esquecer que 
este trabalho foi encomendado para - e, portanto, teve como objetivo verificar o peso das condições geográficas, nessas desigualdades de desenvolvimento, e não a influência da cultura, das instituições, da educação ou de algum outro fator.

Acontece que alguns geógrafos, seguidores talvez sem o perceber da tradição geográfica francesa com a sua crítica apressada e mal feita ao "determinismo geográfico" [uma crítica, ou melhor, um xingamento que não conseguiu discernir o princípio do determinismo deste determinismo particular, que não conseguiu enfim entender a diferença entre um estudo que investiga até que ponto as condições geográficas influenciam as características ou o desenvolvimento de uma comunidade ou de uma sociedade, algo perfeitamente aceitável do ponto de vista científico, de um apriorismo que vê a natureza como condicionante deste mesmo desenvolvimento] têm uma espécie de paranoia, uma recusa por princípio em sequer ouvir falar numa possível influência do clima ou da localização ou da carência de recursos naturais no atraso de algum país ou região. Como assinalou um geógrafo britânico ${ }^{(5)}$, isso foi uma espécie de autocensura que muito atravancou as pesquisas geográficas e que, na história da geografia no século $\mathrm{XX}$, contribuiu para manter certo atraso na geografia humana e em especial na econômica.

(São Paulo, outubro de 2006)

NOTAS:

(*) Professor Livre Docente do Depto. de Geografia da FFLCH da Universidade de São Paulo.

(1) Ver a esse respeito as obras de KRUGMAN, P. Development, Geography, and Economic Theory. Massachussets, MIT Press, 1997; KRUGMAN, P. Geography and Trade. Massachussets, MIT Press, 1993; KRUGMAN, P. "Increasing returns and economic geography", in Journal of Political Economy. Agosto de 1991, n.99, pp. 483-99; KRUGMAN, P., FUJITA M. e VENABLES, A. Economia espacial. São Paulo, Futura, 2002; SACHS, J. O fim da pobreza. São Paulo, Cia. das Letras, 2006; e SACHS, J. "Notes on a new sociology of economic development", in HUNTINGTON, S. (Org.). Culture matters. Nova York, Basic Books, 2000.

(2) LANDES, David S. Riqueza e a pobreza das Nações. Rio de Janeiro, Campus, 1998.

(3) Sobre este item, cf. as análises percucientes de MORIN, Edgar. Introduction à la pensée complexe. Paris, Seuil, 2005. 
(4) Esse mito na verdade foi construído por franceses (La Blache, Durkheim e principalmente Lucien Fèbre) no início do século passado e teve motivações corporativistas (sociólogos e historiadores, num viés positivista, acusavam Ratzel, especialmente na sua geografia política, de estar "invadindo o seu objeto de estudos") e também patrióticas (havia na época um intenso clima de rivalidade entre a Alemanha e a França, em especial um rancor dos franceses pelas derrotas que sofreram nas guerras napoleônicas e na guerra francoprussiana de 1870-71). Mas sem dúvida que existiram pensadores adeptos de um determinismo geográfico, mesmo sem usar essa identificação, pelo menos até meados do século XIX. [Depois isso foi declinando em função dos avanços tecnológicos com a Revolução Industrial e o crescente poderio das sociedades modernas sobre o seu meio ambiente. Por sinal, as condições naturais têm sim um peso significativo nas sociedades tradicionais, embora evidentemente não seja o fator determinante (que em geral não existe, pelo menos não no socialhistórico, no qual uma dada realidade sempre é complexa e resultado de inúmeros fatores interligados, às vezes até num número indeterminado); por esse motivo é absurda a acusação de determinista que alguns geógrafos fazem a Jared Diamond]. Mas não foi o caso de Ratzel, que no fundo buscou perscrutar e sistematizar a dimensão espacial ou geográfica da sociedade humana, em especial da política (estudando territórios, fronteiras, ordem mundial, as relações do Estado com o seu território, etc.), mas nunca afirmou explicitamente que essa dimensão determinaria de forma unívoca a sociedade ou a atividade política. A respeito da construção desse mito da "escola determinista" na geografia germânica, veja-se nosso artigo in http://confins.revues.org/index1162.html.

(5) UNWIN, Tim. The place of Geography. London, Longman Group, 1992, p. 262. 